Jonathan Américo

\title{
Conectividade Insular:
}

\section{um estudo da presença de Spartina alterniflora nas Ilhas de Cananéia e Comprida}

\author{
Dissertação apresentada ao Departamento de \\ Geografia da Universidade de São Paulo, como \\ parte dos requisitos para obtenção do título de \\ Mestre em Geografia Física.
}

Orientador:

Profa. Dra. Sueli Ângelo Furlan

São Paulo 


\title{
Universidade de São Paulo \\ Departamento de Geografia
}

\author{
Conectividade Insular: um estudo da presença de Spartina alterniflora nas \\ Ilhas de Cananéia e Comprida
}

\author{
Jonathan Américo
}

Dissertação apresentada ao Departamento de Geografia da Universidade de São Paulo, como parte dos requisitos para obtenção do título de Mestre em Geografia Física.

Yara Schaeffer Novelli

Professora Doutora do Instituto Oceanográfico da Universidade de São Paulo

Jurandyr Luciano Sanches Ross

Professor Doutor do Departamento de Geografia da Universidade de São Paulo

Sueli Ângelo Furlan

Professora Doutora do Departamento de Geografia da Universidade de São Paulo

São Paulo 
"um passo à frente e você não está mais no mesmo lugar..."

C.S. 
Sumário

Apresentação........................................................................................................................

Introdução.......................................................................................................................................

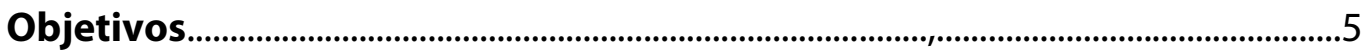

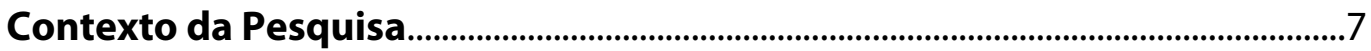

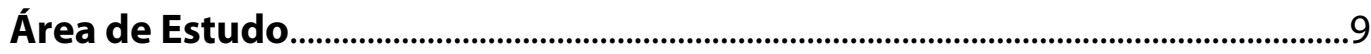

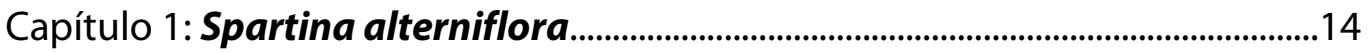

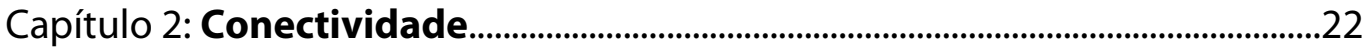

História natural e manejo da vida selvagem........................................22

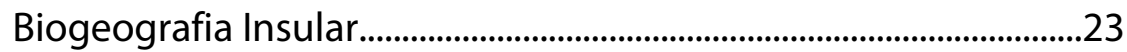

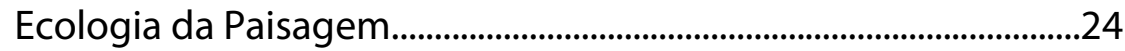

Conectividade .................................................................................................26

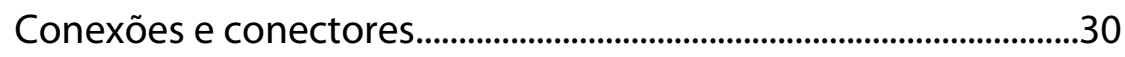

Corredores e Conectividade....................................................................35

Movimento..............................................................................................36

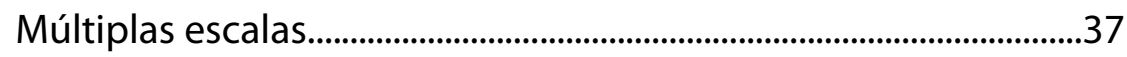

Capítulo 3: Sedimentação...................................................................................................40

Análises de Campo..........................................................................................................50

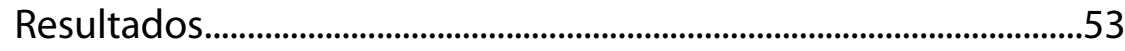

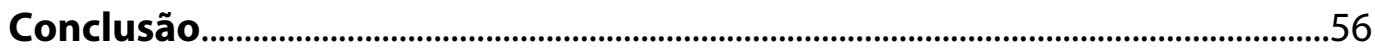

Considerações Finais.......................................................................................................60

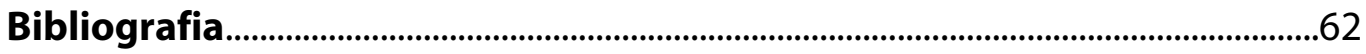




\section{Figuras}

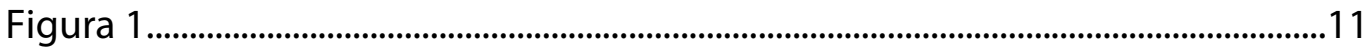

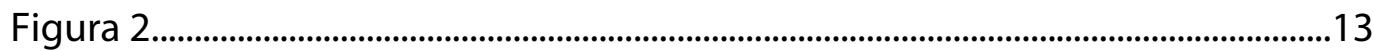

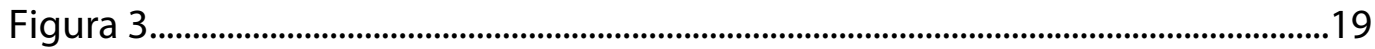

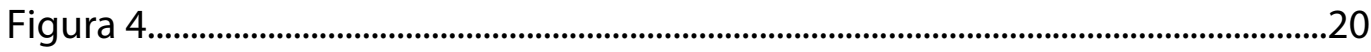

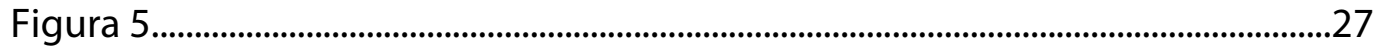

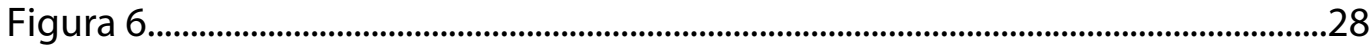

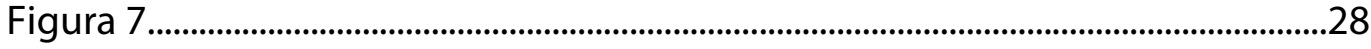

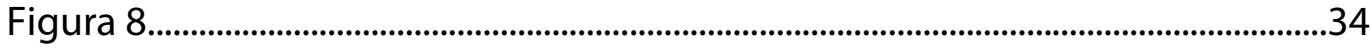

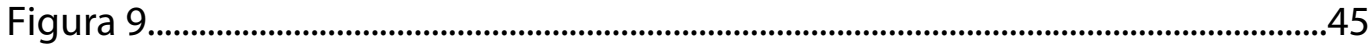

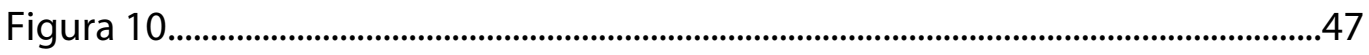

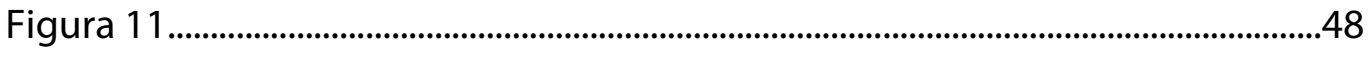

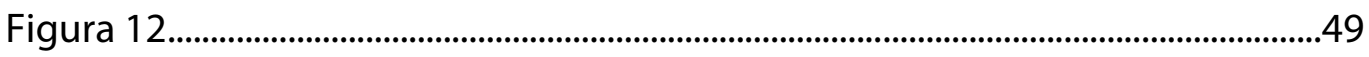

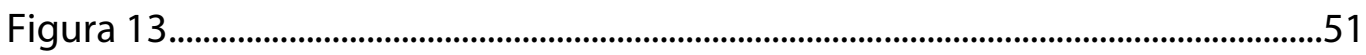

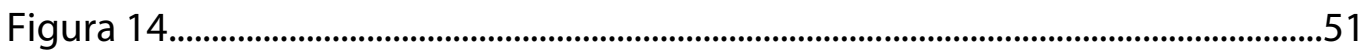

Mapas

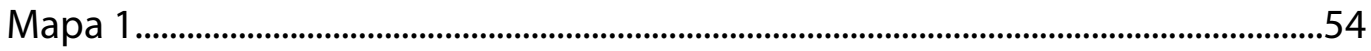

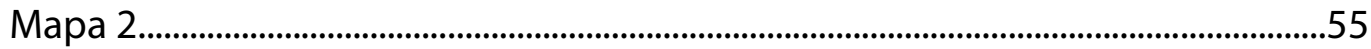

\section{Fotos}

Foto 1 
Finalizar este trabalho é um ato de agradecimento. À todos aqueles que, de alguma maneira, me ajudaram. Que ensinam a me organizar e desorganizar na medida certa.

Obrigado, Sueli! A pessoa mais simpática que eu já conheci. A pessoa mais simpática que eu possa vir a conhecer. Sua ajuda e carinho estão na história da minha vida. Você me acolheu na vida acadêmica paulistana de forma generosa.

Aos meus pais, que sempre me mostraram a importância do estudo. Que me incentivaram à buscar diversas formas de conhecimento. Que são o exemplo de pais no meu mundo.

Aos professores Euler Sandeville Junior e Sérgio Tadeu Meirelles, que ministraram, talvez, a disciplina mais intensa que já vivi.

À oportunidade de conviver com Yara Schaeffer Novelli e seu conhecimento admirável.

Ao Luiz Bittar Venturri e à Marisa de Souto Matos Fierz, que me acolheram na chegada à Universidade de São Paulo.

A todos que tanto me ensinaram, dentro e fora das disciplinas. Às disciplinas em si, e tudo que elas me fizeram buscar.

À Ana e toda Secretaria de Pós-Graduação do Departamento de Geografia, que sempre se preocuparam em ajudar com toda a burocracia de um ambiente acadêmico.

Aos meus lindos amigos. À amizade, que permanece fácil e plena, mesmo com os encontros tão raros.

À Bárbara bela, que faz amar ser a forma mais natural de viver. 


\section{Resumo}

Os manguezais do Sistema Lagunar Cananéia-lguape, no extremo sul do litoral do estado de São Paulo, possuem, em suas franjas mais externas, a presença da gramínea Spartina alterniflora, que exerce papel fundamental na fixação de sedimentos que poderão se tornar áreas de propagação do mangue. Pioneiras na região alagada do mangue, a Spartina segura e prepara o substrato para as plântulas de espécies de mangue se instaurarem. O mapeamento da Spartina alterniflora nas Ilhas de Cananéia e Comprida, onde estas ilhas margeiam o mesmo canal lagunar, possibilitou identificar as áreas propensas ao seu crescimento. Os pontos de baixa energia do fluxo de água do canal mostraram-se favoráveis ao surgimento de bancos de Spartina. A troca contínua de sedimentos e nutrientes existentes em um ambiente lagunar rico em manguezais, associada à grande capacidade de captação e fixação da Spartina, resultou em um estudo de conectividade entre duas ilhas.

Palavras-chave: Spartina alterniflora, manguezais, sedimentação, conectividade. 


\section{Abstract}

The Cananéi-Iguape lagoon system, in the south shore of São Paulo state, has the presence of the cordgrass Spartina alterniflora on the outer side of the mangroves. The cordgrass has a fundamental role in the fixation of sediments which will be the mangrove's propagation areas. Pioneers in the mangrove wetlands, Spartina holds and prepare the substrate for the mangrove seedling establishment. Mapping the presence of Spartina alterniflora in the islands Ilha de Cananéia and llha Comprida, allowed to identify the prone areas for its growth. The points of low energy in the river were more favorable to create banks of Spartina. The continuous exchange of sediments and nutrients which exists in a mangrove lagoon system, associated with the great ability of Spartina to capture and establishment, resulted in a study of connectivity between two islands.

Keywords: Spartina alterniflora, mangroves, sediments, conectivity. 


\section{Apresentação}

O modelo de conservação biológica utilizado hoje em dia nas principais políticas que tratam o meio ambiente, baseia-se em áreas e fragmentos, na maior parte das vezes remanescentes modificados que simbolizam toda uma região do passado que foi mais extensa e continua. Resguardados devido à sua importância perante a biodiversidade, comunidades, recursos, etc, tais fragmentos mantiveram-se totalmente ou parcialmente isolados, o que contribuiu para um decréscimo de suas importâncias antes ressaltadas.

A região Estuarino-Lagunar de Cananéia, no extremo litoral sul do estado de São Paulo, possui características importantes à preservação e que pode contribuir para o conceito de um novo modelo de conservação: a conectividade entre os fragmentos. À sudeste da borda sul do continuum de Paranapiacaba, mesmo com seu isolamento inerente à uma ilha, o estuário realiza importante conectividade de matéria e energia entre o continente, o estuário e o mar.

Este é um estudo que procura, à partir das bases da ecologia da paisagem, diagnosticar toda a estrutura da paisagem; investigar as relações dos elementos dentro e entre ecossistemas (unidades espaciais); e mudanças significativas que ocorreram ao longo do tempo que possam ter alterado ou influenciado a área em alguma forma. Os resultados destas pesquisas irão dar o suporte necessário para poder estabelecer as rotas mais importantes e favoráveis à conectividade. 


\section{Introdução}

Com uma extensão de mais de 8.000 km de faixa litorânea, o Brasil possui uma grande potencialidade de uso de sua costa, ao mesmo tempo em que pode apresentar um grande risco se não houver uma utilização adequada desta relevante área. O conhecimento da dinâmica litorânea abrange várias esferas do conhecimento (cultural, econômica, científica, etc), incluindo toda a história de colonização do nosso País e praticamente de todas as américas..

\footnotetext{
Partindo-se do conhecimento de que em todas as áreas coloniais americanas, o colonizador chegou inicialmente nas novas terras por via marítima, entende-se por que as zonas litorâneas foram as primeiras a conhecer núcleos de povoamento. Assim, todos os fluxos de colonização do Novo Mundo partiram de centros de difusão assentados na costa, que articulavam a hinterlândia explorada com as rotas oceânicas que alcançavam tal exploração. (Moraes, 1999, p.31).
}

Caracterizado desde o período da colonização como um país de exportação de matéria prima, a faixa litorânea brasileira sempre foi o palco de atividades portuárias que se intensificaram à medida que o país se industrializava. De acordo com Diegues $(2001$, p.108) a partir do final da década de 1960 "os pólos químicos, centros industriais, corredores e portos de exportação cresceram em número e intensidade sem avaliação prévia dos impactos ambientais deles decorrentes", colocando em risco os ecossistemas presentes na zona costeira bem como a sua importância e funcionalidade para as populações que estão diretamente ligadas à eles.

A zona costeira brasileira abriga uma vasta gama de ecossistemas de enorme importância biológica, cultural e econômica. Do ponto de vista econômico, tais ecossistemas são a fonte de renda de várias populações costeiras que dependem diretamente dos seus recursos. Biologicamente, os ecossistemas que estão nessa área de interação entre mar, terra e atmosfera 
apresentam enorme valor uma vez que são habitats de inúmeras espécies animais e vegetais. Sobre esse aspecto, Diegues um estudioso dos povos do Mar (2001, p.107) reconhece que:

\begin{abstract}
Os ecossistemas litorâneos e costeiros são habitats de uma grande parte dos recursos marinhos brasileiros, pois são áreas de criação, refúgio permanente ou temporário de inúmeras espécies de peixes, crustáceos e moluscos capturados pela pesca industrial e artesanal. Além disso, são habitats para inúmeras espécies de aves residentes ou migratórias e animais importantes da fauna brasileira (Diegues, 2001).
\end{abstract}

A importância atribuída aos ecossistemas costeiros, seja ela ambiental, cultural, econômica, etc, possui aspectos comuns que se fundem, gerando estratégias para o uso dos ecossistemas. Áreas de grande valor biológico representam também grande valor econômico para as comunidades que vivem da exploração desses recursos, ou ainda como áreas preservadas que são grandes atrativos para atividades turísticas que também possui seu fim econômico. Desse modo, se faz necessário um estudo para gerenciar esses interesses que muitas vezes se mostram conflitantes.

A ampla variedade de recursos naturais que a zona costeira possui é colocada em risco pelas atividades antrópicas mal planejadas e que visam muitas vezes somente o aspecto econômico, uma vez que cresce a população que habita a região litorânea. Dessa forma, cada vez mais fica explícita a necessidade do Planejamento Ambiental e Territorial Costeiro, que nos possibilita caminhar na direção de uma relação positiva entre desenvolvimento econômico e o uso sustentável dos recursos naturais litorâneos.

A area de estudo desta pesquisa situa-se no Complexo Estuarino-Lagunar de Cananéia que possui as características necessárias e favoráveis ao desenvolvimento de manguezais que, por sua vez, apresentam o potencial de ocorrência da gramínea Spartina alterniflora, espécie 
escolhida como bioindicadora neste estudo. . Tal espécie exerce importante papel ecológico na ciclagem de nutrientes, na retenção e deposição de sedimentos, o que favorece a cadeia alimentar da microfauna e a expansão da franja externa do manguezal.

A ilha de Cananéia está localizada em um ponto que possibilita conectividade ${ }^{1}$ com outras unidades de conservação vizinhas. A cidade se encontra a menos de 15 quilômetros a sudeste do Parque Estadual do Jacupiranga, que juntamente com o Parque Estadual Intervales, Parque Estadual Carlos Botelho, Estação Ecológica de Xitué, Parque Estadual Turístico do Alto Ribeira (PETAR) e Zona de Vida Silvestre da APA da Serra do Mar, formam o continuum ecológico de Paranapiacaba.

1 A habilidade de uma espécie de utilizar dos recursos de uma área está totalmente relacionada à sua habilidade de chegar até esta área. O que determina esta habilidade não é somente a distância, mas também a natureza biofísica da rota que será utilizada, além do comportamento da espécie. Alguns caminhos facilitam, ou não impedem o movimento entre áreas; outros obstruem, em diferentes níveis, o movimento das espécies. Devido à grande importância do movimento das espécies, conclui-se uma terceira medida de estrutura da paisagem, denominada 'conectividade'. "Conectividade da paisagem é o grau em que a paisagem facilita ou impede o movimento entre áreas fontes" (Taylor et al., 1993). 


\section{Objetivos}

O presente projeto de pesquisa tem como objetivo geral o estudo da estrutura e dinâmica entre o ecossistema manguezal presente na Região Estuarino Lagunar de Cananéia (SP), na área de interfácie entre a Ilha de Cananéia e Ilha Comprida. À partir de abordagens da ecologia da paisagem, biogeografia insular e seus conceitos correlatos, ressaltando o potencial e importância da área para a conservação.

\section{Objetivos Específicos}

O principal objetivo específico, que norteia e ordena toda a pesquisa, consiste em mapear a distribuição geográfica da espécie Spartina alterniflora na área que se limita ao norte pela Vila de Pedrinhas (Ilha Comprida) até a Base do Instituto Oceanográfico (Ilha de Cananéia), limite sul. A presença da espécie, quando se dá, ocorre na franja externa do manguezal nas bordas do canal, o que delimita a área de estudo às margens do Mar de Cananéia (Figura 2).

Através dos pontos de ocorrência da Spartina alterniflora e levando-se em conta os aspectos biológicos da planta, poderá se fazer um estudo de conectividade entre as ilhas, o que caracteriza um outro objetivo específico.

Surgem metas e passos essenciais que, a medida que vão sendo atingidos, fornecem a base para o entendimento da dinâmica e heterogeneidade da região. 
São eles:

- caracterização estrutural, uma diagnose da fauna, vegetação, hidrografia, solo, geomorfologia e geologia, e uma análise das relações existentes entre estes elementos e possíveis ecossistemas;

- conectividade, estabelecer as possíveis áreas chave que garantem um fluxo genético e uma real conservação.

Por possuir as características naturais favoráveis para a existência e manutenção dos manguezais, e estes sendo fonte econômica para as comunidades locais, a ilha de Cananéia se adequa perfeitamente à visão que Marta Vanucci propõe em seu livro Os Manguezais e Nós², sobre o uso econômico racional dos manguezais:

- "tentar ter em mãos um quadro claro dos papéis que os manguezais desempenham na zona costeira sob diferentes condições, procurando uma resposta para a questão: se o gerenciamento com intenção de maximizar a produção de um só recurso é, a longo prazo, mais conveniente do que o gerenciamento do ecossistema como um todo, visando à otimização de vários recursos;

- estabelecer os critérios que deveriam ser usados para decidir o que se deve fazer em cada caso específico para um aproveitamento racional dos manguezais em áreas de interesses fortemente conflitantes". 


\section{Contexto da pesquisa}

Desde a primeira área de conservação ambiental criada no mundo até os dias de hoje vivemos políticas de conservação baseadas em áreas e fragmentos, na maior parte das vezes remanescentes menos modificados pelo homem que simbolizam toda uma região supostamente próxima do "original". Resguardados devida à sua importância perante a biodiversidade, comunidades, recursos, etc, tais fragmentos mantiveram-se totalmente ou parcialmente isolados, o que contribuiu muitas vezes para um decréscimo de suas importâncias antes ressaltadas e em alguns casos o isolamento também levou a alterações indesejáveis nos ecossistemas supostamente intocados.

Por outro lado pesquisas sobre dinâmica da fragmentação tem apontado que a conexão entre framentos constitui um aspecto importante no fluxo gênico (Alves \& Metzger, 2002; Metzger, 2003)

Os estudo dos corredores ecológicos e conectividade é, relativamente, recente e sua aplicação restringe-se à poucas áreas do planeta. No Brasil, desde julho de 2000, o Sistema Nacional de Unidades de Conservação (SNUC) faz menção aos corredores ecológicos no Capítulo IV: “Da Criação, Implantação e Gestão das Unidades de Conservação", Artigo 25:

As unidades de conservação, exceto Área de Proteção Ambiental e Reserva Particular do Patrimônio Natural, devem possuir uma zona de amortecimento e, quando conveniente, corredores ecológicos. 
O Governo Federal mantém o Projeto Corredores Ecológicos, integra os esforços do Programa Piloto para a Proteção das Florestas Tropicais do Brasil (PPG7), com o objetivo de otimizar os benefícios oferecidos pelas florestas tropicais, em acordo com as metas de desenvolvimento do País. O Corredor Central da Amazônia e os Corredores de Biodiversidade da Mata Atlântica compõem o projeto em um âmbito nacional. O Estado de São Paulo, com seus órgão ambientais públicos e unidades acadêmicas, avançam suas pesquisas e implantação do Continuum Ecológico de Paranapiacaba, com mais de 120 mil hectares na região do Vale do Ribeira.

O estudo da conectividade (potenciais e implementações) apresenta-se fundamental à conservação e sustentabilidade. Este projeto, ao se propor a entender a dinâmica natural de Cananéia, em toda sua complexidade e heterogeneidade, assume este papel ecológico de extrema importância. Através da ecologia da paisagem, este trabalho procura seguir um caminho pertinente ao entendimento das relações entre os elementos naturais, gerando dados e bases para uma melhor gestão e possível conectividade. 


\section{Sistema Cananéia-Iguape}

O Sistema Cananéia-Iguape, na forma que conhecemos hoje, remete sua origem a 120.000 anos atrás quando o nível médio relativo do mar (NMRM) se encontrava 8 metros acima do nível atual, alcançando o sopé da Serra do Mar e recobrindo a Formação Pariquera-Açu com argilas transicionais e marinhas (Sugio \& Martin, 1978). Em um segundo momento, a Regressão Pleistocênica possibilita depósitos de cristas praiais que, por sua vez, recobrem depósitos arenosos pleistocênicos. A 17.000 anos antes do presente (A.P.) estima-se que o NMRM estava 110 metros abaixo do atual, caracterizando este terceiro momento com a erosão dos depósitos da Formação Cananéia pelos rios da planície costeira. O quarto momento e último evento transgressivo, denominado Transgressão Santos ou Transgressão Holocênica, o NMRM, 4 metros acima do atual, invade áreas rebaixadas formando a grande área lagunar e depositando sedimentos areno-argilosos ricos em matéria orgânica. No quinto e último estágio, o NMRM se estabiliza no nível atual formando cristas praiais regressivas, o que firma a presença da Ilha Comprida (Figura 1).

Segundo Besnard (1950a), o primeiro cenário do Sistema Cananéia-Iguape apresenta uma série de reentrâncias margeadas pela Serra do Mar e algumas ilhas. O segundo cenário seria caracterizado pelas correntes de maré modelando as ilhas através de processos de erosão e sedimentação. Os bosques de mangue apareceriam em um terceiro momento, consolidando os sedimentos mais finos no fundo dos rios e canais. O último momento é representado pelo cenário atual, resultante da sedimentação e erosão realizada pelas correntes de maré e ação dos 
rios (Cunha-Lignon, 2001).

Situado no extremo sul do litoral do Estado de São Paulo, o sistema é composto por quatro ilhas principais formadas principalmente de sedimentos quaternários e rochas cristalinas do précambriano. Sua drenagem se dá, principalmente, através do Rio Ribeira do Iguape além de canais lagunares, gamboas e rios que separam as Ilhas do Cardoso, Cananéia, Comprida e Iguape. Dentre elas, Iguape é a única ilha artificial, originada à partir da abertura do canal Valo Grande, que foi construído em meados do século XIX com o objetivo de facilitar a navegação na parte final do Rio Ribeira do Iguape (Cunha-Lignon, 2001). Em 1978, o Valo Grande foi fechado pelo Governo do Estado de São Paulo e sendo reaberto em 1983. Quando aberto pela primeira vez, era um canal de 4,40m de largura e atualmente, devido a erosão das margens, apresenta mais de 300m e comportando grande parte da vazão do Rio Ribeira (Besnard, 1950b).

O Sistema Cananéia-Iguape conecta-se com o oceano via três desembocaduras: Icapara (norte), Cananéia (centro) e Ararapira (sul). Por ser uma planície costeira, os rios e canais do sistema são influenciados tanto por águas oceânicas e correntes de maré quanto por águas doces que chegam do continente (Tessler \& Souza, 1998).

A região apresenta temperatura média anual de $23,8^{\circ} \mathrm{C}$, sendo a temperatura média mensal mais alta $27,8^{\circ} \mathrm{C}$ em fevereiro, e a média mensal mais baixa $19,8^{\circ} \mathrm{C}$ em julho (Silva, 1989). Na região, a maré é do tipo mista, com altura média de 0,81m (Mesquita \& Harari, 1983).

Os valores pluviométricos apresentam média anual de $2300 \mathrm{~mm}$, com valores máximos de janeiro a março com média mensal de $266,9 \mathrm{~mm}$ e mínimos em julho e agosto com média mensal de 95,3mm (Silva, 1989). 

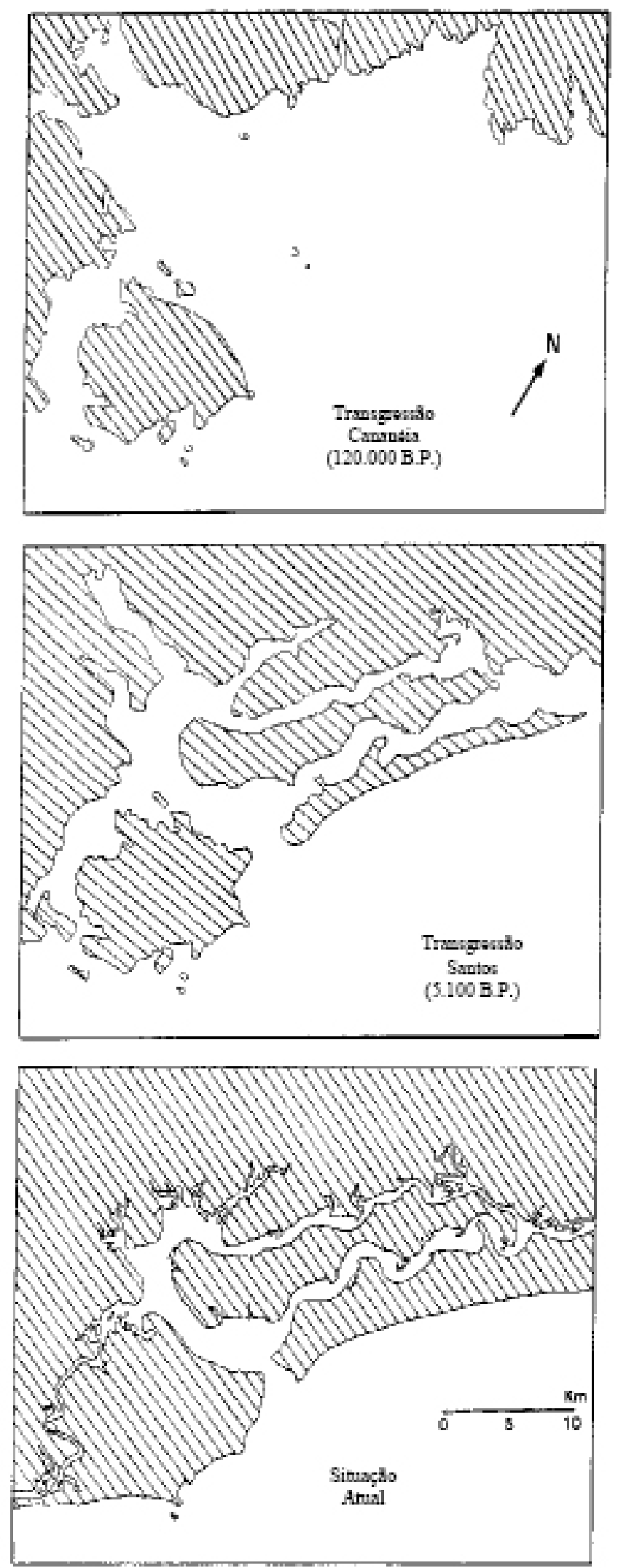

Figura 1: Esquema de evolução quaternária da planície de Cananéia-Iguape, segundo Suguio \& Martin (1978), elaborado por Bonetti Filho (1995) (In: Cunha-Lignon, 2001). 
Atualmente, quanto à salinidade, o sistema é caracterizado como parcialmente misturado e altamente estratificado (tipo 2b), durante as estações de verão, outono e primavera nas marés de sizígia (Bérgamo, 2000). Durante o inverno, na maré de sizígia, no outono e na primavera nas marés de quadratura o sistema é classificado como parcialmente misturado e fracamente estratificado (tipo 2a) (Bérgamo, 2000).

\section{Geologia e geomorfologia: síntese para a região}

A Planície Costeira de Cananéia-Iguape está, em sua grande parte, coberta por sedimentos arenosos do quaternário, compostos por areias finas selecionadas e homogêneas, de origens continentais na base e marinhas no topo. Também inserida nas Formações Pariquera-Açu, Cananéia e Ilha Comprida, esses depósitos estão assentados sobre o Embasamento Cristalino pré-cambriano relacionados ao Grupo Açungui (Karniol-Marquez, 2007).

O Embasamento Cristalino aflora nos arredores da ponte sobre o canal de Cubatão e na parte oceânica das Ilhas do Bom Abrigo e Cardoso. Também afloram rochas alcalinas cenozóicas que sustentam o morro de São João na Ilha de Cananéia, e o morro do Morrete na Ilha Comprida (Spinelli, 2003). Pontões do Embasamento também separam grandes planícies formadas essencialmente por depósitos marinhos flúvio-lagunares (Suguio \& Martin, 1986).

O litoral paulista e sul fluminense pode ser dividido em cinco principais unidades morfológicas, de acordo com os limites naturais dos pontões do Embasamento Cristalino: (1) Cananéia-Iguape, (2) Itanhaém-Santos, (3) Bertioga-Ilha de São Sebastião, (4) Ilha de São Sebastião-Serra do Parati e (5) Baía da Ilha Grande. Com transições suaves entre uma unidade e outra, suas diferenças 
morfológicas podem ser explicadas por dinâmica de sedimentação e tectônica (Sugio \& Martin, 1986).

A Unidade Cananéia-Iguape é formada por uma planície sedimentar litorânea de origem cenozóica, do tipo marinha, com altitudes que variam de 0 a 20 metros e declividade inferior a 2\%, caracterizando a Planície Litorânea de Iguape-Cananéia (Ross, 1997).

Com uma extensão de $130 \mathrm{~km}$ de comprimento por 40km de largura, apresenta uma complexa rede de drenagem composta por canais lagunares, rios e gamboas, com o Ribeira do lguape sendo o principal rio da planície e com maior vazão do litoral paulista (Suguio \& Martin, 1986).

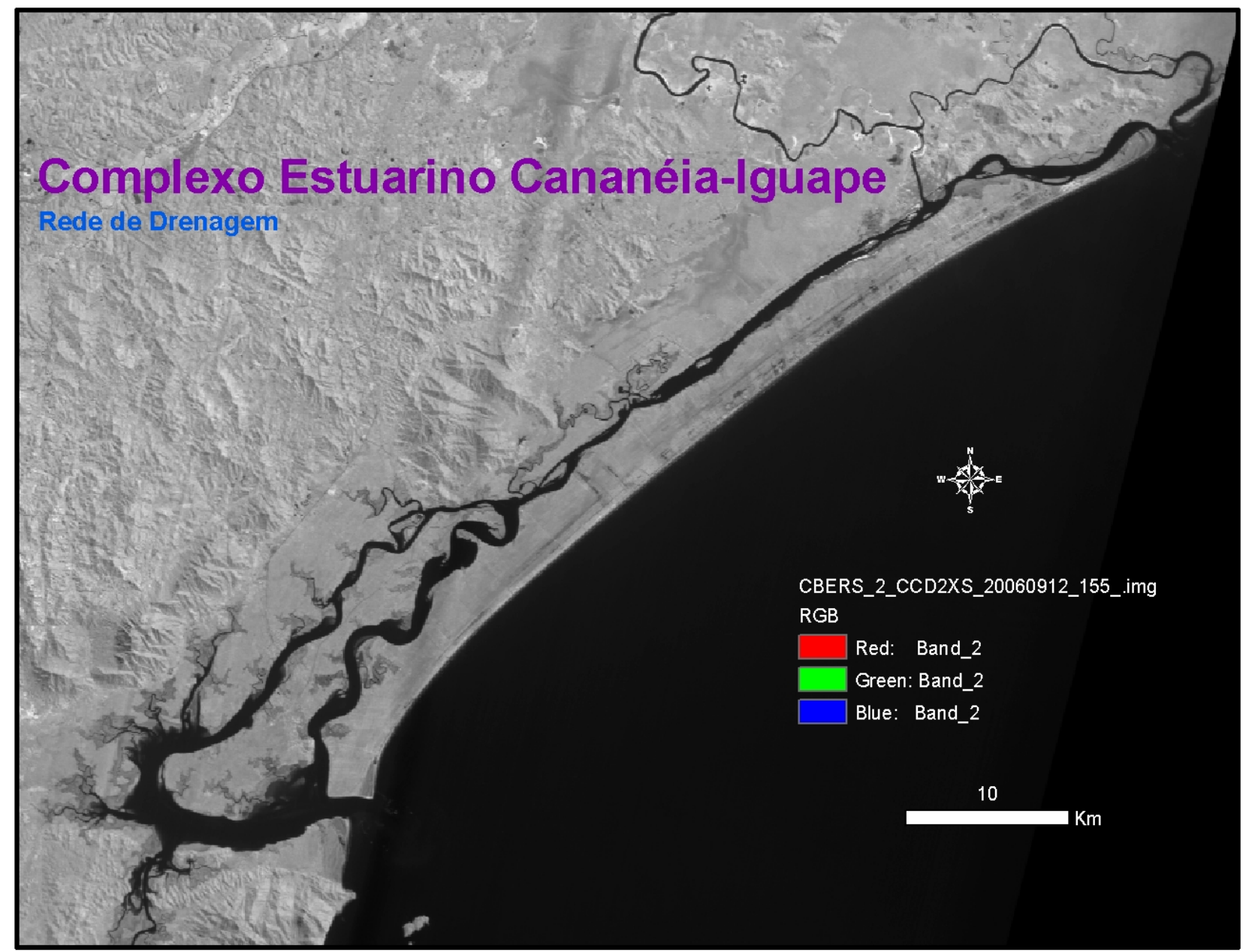

Figura 2: Composição de imagem CBERS (2006) ressaltando corpos d'água (oceano, rios e gamboas) na cor preta (Fonte/Imagem: Instituto Nacional de Pesquisas Espaciais, INPE). 


\section{Capitulo 1 - Spartina alterniflora}

O manguezal possui uma biota singular. Dentre as espécies herbáceas neste estudo focamos a

Spartina. O gênero Spartina é formado por $16^{3}$ espécies de gramínias perenes, pertencente, segundo APG II (Angiosperm Phylogeny Group, 2003), à família Poaceae. O gênero é nativo de toda a costa do Oceano Atlântico, ocorrendo principalmente nas Américas do Norte e Sul. Ocorrências menores também podem ser constatadas na costa Atlântica da Europa e África, e também na costa Pacífica da América (Mobberley, 1956).

As folhas caracterizam-se por serem bem articuladas; lígulas ciliadas; inflorescência em forma de panículas; espiguetas com uma única flor entre ráquis; glumas assimétricas, membranosas e, em algumas espécies, a gluma superior ultrapassa a lema; fina pálea hialina também ultrapassa a lema e envolve completamente o ovário e os estames; ausência de lodícula; flores protogínicas; ausência de sementes na maioria das espécies; e reprodução assexuada através dos rizomas escamosos (Goodman, 1958).

A espécie Spartina alterniflora é uma gramínia adaptada à estuários, ocorrendo na região de entre marés, onde existe variação de salinidade e períodos de exposição e inundação (Adaime, 1977). Dentre as representantes do gênero, Spartina alterniflora é a que se apresenta mais característica de manguezais, não se restringindo à região de marismas (Klein et al., 1981).

Sua ocorrência na América Latina se dá em vários países, extendendo-se desde a fronteira entre México e Estados Unidos, $32^{\circ} \mathrm{N}$, até a Bahia Blanca na Argentina, 34³0'S (Costa \& Davy, 1992). Também distribui-se na costa leste do Canadá e grande parte da costa Atlântica e Pacífica dos Estados Unidos.

3 Mobberley (1956) ressalta o problema de separação taxonômica do gênero, uma vez que os critérios são vagos e inconsistentes, dificultando a identificação precisa de algumas espécies e táxons infraespecíficos. 
S. alterniflora apresenta três alturas distintas em boa parte dos locais onde é encontrada: indivíduos altos, intermediários e baixos, que tendem a ocupar diferentes áreas em regiões de marismas (Teal, 1962; Adams, 1963; Squiers \& Good, 1974). Spartina alta é propensa a ocorrer logo acima da margem do canal e áreas que são regularmente inundadas. Spartina intermediária ocupa o topo dos bancos naturais que ficam acima do canal. Spartina baixa ocorre na parte alta do marisma e, portanto, menos inundada (Teal, 1962; Squiers \& Good, 1974).

Os manguezais representam, de certa forma, uma analogia tropical e subtropical dos marismas, o que não exclui a possibilidade de também encontrar marismas nestas regiões (Costa \& Davy, 1992). A distribuição da Spartina alterniflora nos manguezais parece estar intimamente ligada à ausência, ou atenuação, do dossel em alguma parte do bosque (Chapman, 1974; Reitz, 1961; Tomlinson, 1986). Deste modo, restringe-se à formações pioneiras em clareiras, nas bordas externas rente ao canal ou na costa de estuários (West, 1977; Santos, 1989 apud Costa \& Davy, 1992).

Estudos em North Carolina (Williams and Murdoch, 1969) e em Louisiana (Gosselink \& Kirby, 1974) - ambos nos Estados Unidos da América e o último mais ao sul - mostraram que em latitudes maiores, o crescimento de S. alterniflora começa na primavera e termina no outono, enquanto que em latitudes mais baixas o crescimento pode ser contínuo. Desta forma, existe uma relação entre latitude e produção de biomassa, uma vez que esta produção está ligada às médias anuais mais altas do "standing crop" das latitudes mais próximas à linha do equador (Turner, 1976). Coerentemente, conclui-se também a íntima relação entre temperatura, crescimento e produção dos bancos de Spartina alterniflora. 
Além de latitude e temperatura, outros fatores podem influenciar na produção de biomassa viva como: amplitude de maré, disponibilidade de nutrientes e salinidade. No que diz respeito à amplitude de maré não existe nenhuma explicação plausível, ao passo que vários são os trabalhos que mostram um aumento ou indiferença na possível relação com produção de biomassa (Nixon \& Oviatt, 1973a, 1973b; Valiela \& Teal 1974).

A dificuldade encontra-se em saber se a maré trará os nutrientes necessários para um acréscimo na produção. Sabe-se que o aumento de nitrogênio nos bancos de Spartina alterniflora acarreta em uma maior produção (Tyler, 1967 apud Turner, 1976; Marshall, 1970 apud Turner, 1976; Valiela \& Teal, 1974; Sullivan \& Daiber, 1974; Payonk, 1975 apud Turner, 1976). Do mesmo modo, é forte a correlação entre amônia e fósforo com biomassa, altura e peso, enquanto salinidade não aparenta ser uma variável significante para estes parâmetros. Salinidade da água nos solos tem mostrado ser um fator mais influente do que a salinidade na água de superfície (Nixon \& Oviatt, 1973a).

Vários são os fatores que compõem a dinâmica natural dos manguezais e marismas e que influenciam na produção de biomassa da Spartina alterniflora. Além dos já mencionados, a insolação também é outro importante elemento que pode alterar a produção dentro de uma mesma área. A eficiência da planta em converter energia solar pode variar entre as bordas e os locais mais altos do ecossistema estuarino, o que ressalta ainda mais a latitude e temperatura como aspectos importantes na produção de biomassa (Turner, 1976).

A produção de biomassa subterrânea é responsável por grande parte da produção total de biomassa da S. alterniflora. A biomassa de seus rizomas e raízes pode ser até 2.5 vezes maior que a biomassa aérea (Nixon \& Oviatt, 1973; Cammen et al, 1978). A biomassa viva também contribui 
2.5 vezes mais que a biomassa morta, o que indica a grande capacidade de reprodução vegetativa da planta através de seus rizomas que produzem embriões ao longo de todo o ano (Panitz, 1992).

Os níveis de fósforo da Spartina são altos, e podem refletir as necessidades da planta (RodewaldRudescu, 1974 apud Panitz, 1992). Durante a primavera, os rizomas transferem fósforo para os pequenos gérmens de Spartina. No verão, os níveis de fósforo aumentam na parte aérea da planta. No começo do outono, com a morte de boa parte dos indivíduos, o fósforo volta para os rizomas da planta. Ainda com uma alta taxa de mortalidade durante o inverno, há acumulação de detritos, que liberam fósforo na água ou nos sedimentos e que podem ser metabolizados ou liberados para as camadas oxidadas ${ }^{4}$. Todo este processo acelera a disponibilidade de fósforo para circulação biogênica do ecossistema (Esteves, 1979 apud Panitz, 1992).

As folhas da Spartina alterniflora contém grande quantidade de polifenol, o que a deixa pouco atraente para herbívoros. A taxa de polifenol é o que determina o sabor dos vegetais para seus possíveis consumidores, e sua concentração é inversamente relacionada à intensidade de ser ingerida (King \& Health, 1982). O polifenol também é importante na formação de substâncias húmicas, que é fundamental na formação de sedimentos e produção primária (Bianchini, 1982, 1984).

A Spartina alterniflora também realiza um importante papel ecológico como grande fornecedor de detrito e energia orgânica para o ecossistema (Odum \& de la Cruz, 1967; Darnell, 1967; Panitz, 1992). Detritos orgânicos representam um mecanismo de armazenamento, transporte e amortecimento para o ecossistema estuarino: o material orgânico produzido em um certo 
período é liberado mais tarde, seja no mesmo local ou em um ponto correnteza abaixo; capacidade de disponibilizar nutrientes durante as temporadas de baixa produção primária (Darnell, 1967b).

Detritos orgânicos são todos os tipos de materiais biogênicos, em seus vários estágios de decomposição microbial, que representam fontes de energia para as espécies consumidoras (Darnell, 1967a). Em marismas ou nas porções dos manguezais ocupadas por Spartina, os detritos orgânicos são a ligação entre a produção primária e a secundária, uma vez que apenas uma pequena parte da produção destas áreas são consumidas ainda quando vivas (Odum \& de la Cruz, 1967). Estudos realizados nos estuários da Georgia estimaram que quase 95\% dos detritos orgânicos da llha Sapelo é composto de resíduos de Spartina, e que esse material orgânico é produzido e exportado durante todo o ano (Odum \& de la Cruz, 1967).

Cerca de $60 \%$ da produção anual primária da Spartina alterniflora está relacionada ao cresimento de suas raízes e rizomas que, uma vez morta, disponibiliza esta taxa de carbono para os organismos decompositores presentes (Wiegert, 1977). A importância da Spartina alterniflora para o estuário aumenta ainda mais, uma vez que ao ser decomposta, seus detritos sofrem um enriquecimento protéico dado através da ação das populações microbiais, gerando uma grande fonte nutricional para a cadeia alimentar (Odum \& de la Cruz, 1967). 


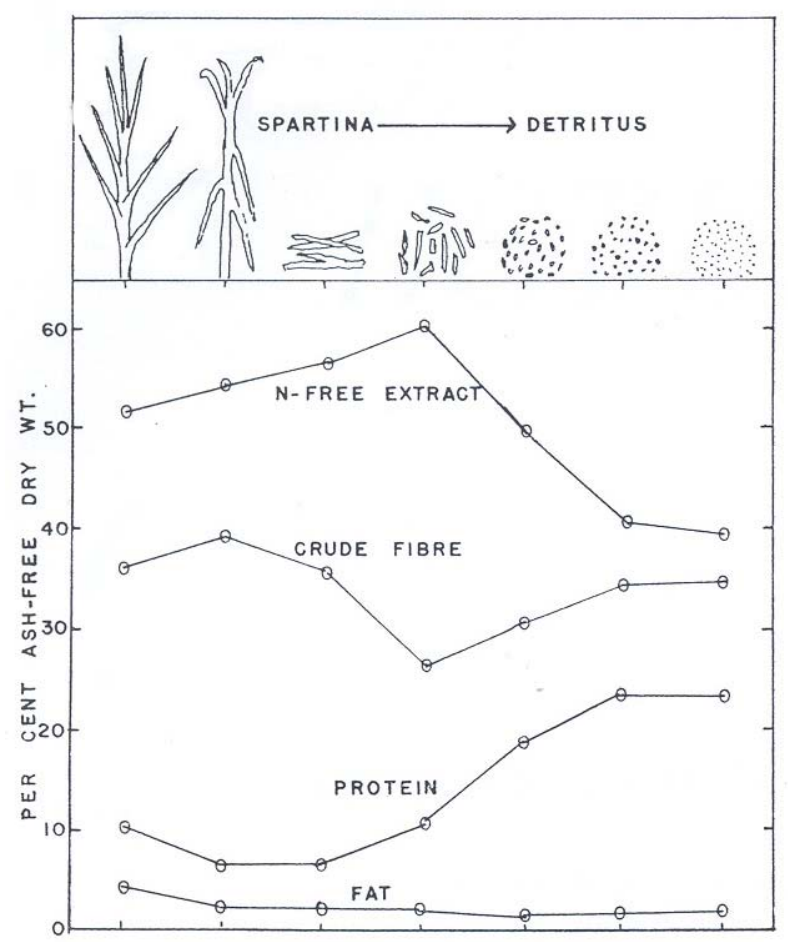

Figura 3: Composição nutritiva dos estágios sucessivos de decomposição da Spartina, mostrando o aumento de proteínas e o decréscimo de carboidratos (Odum \& de la Cruz, 1967).

Estudos realizados nos "salt-marshes" da Georgia, EUA, mostraram que a deposição de partículas inorgânicas é maior, atingindo o máximo de deposição, nas áreas próximas aos canais e águas abertas (menos que 1,5m), e gradualmente, mas significativamente, decrescem à medida que aumenta a distância para o interior (Figura 4) (Leonard et al, 2002).

Pesquisas na costa leste da Península de Delmarva, no estado da Virgina, EUA, complementam os dados do estado da Georgia ao mostrar que os processos de deposição de sedimentos ocorrem durante todas as marés, enquanto as taxas de concentração de sedimentos suspensos aumenta durante a maré alta, o que, consequentemente, aumenta a taxa de deposição (Christiansen et al, 2000). 


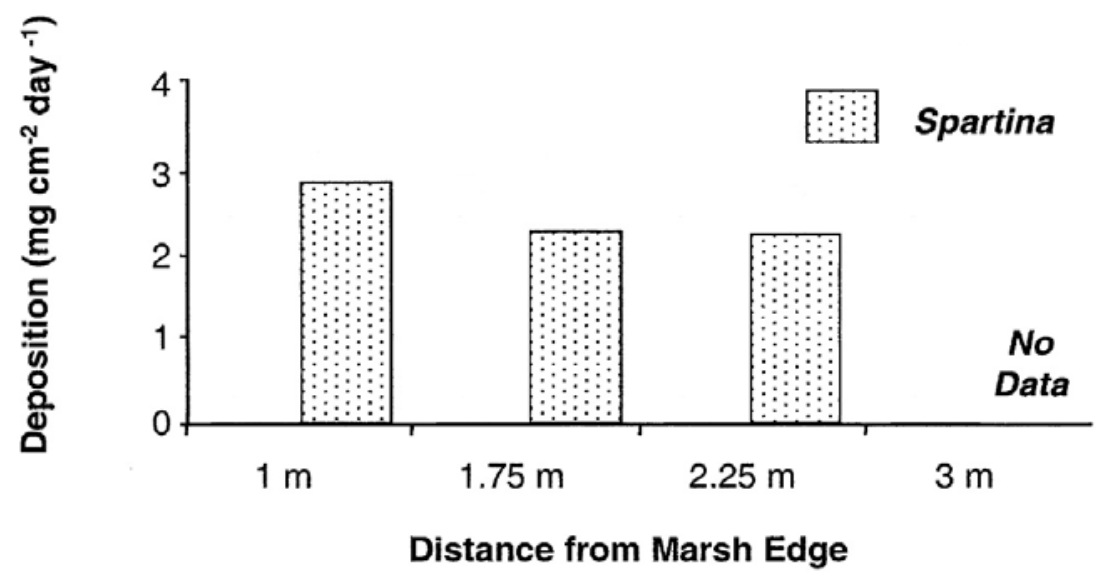

Figura 4: Média de deposição de sedimentos de acordo com a distância da borda para o interior do marisma ocupado por Spartina (adaptado de Leonard et al, 2002).

Análises realizadas em bancos de Spartina alterniflora indicaram a incapacidade do fluxo de marés de resuspender ou remobilizar os sedimentos uma vez depositados (Christiansen et al, 2000). Estes dados, associados à sua própria decomposição, mostram a grande contribuição da Spartina para a formação estrutural de sedimentos, que pode servir de substrato para a ocupação de espécies secundárias, levando-se em conta a condição perene da gramínea (Panitz, 1992).

Fica claro o papel ecológico realizado pela gramínea Spartina alterniflora no ambiente estuarino, bem como sua importância na ciclagem de nutrientes, no fornecimento de detritos e energia, na participação na cadeia alimentar e na sedimentação da área próxima ao canal.

Alguns tópicos vêm sintetizar o conhecimento reunido neste capitulo sobre a função realizada pela S. alterniflora nos "salt-marshes" e manguezais:

- grande capacidade de reprodução vegetativa, e desta forma dar continuidade à todo seu 
papel no ecossistema;

- liberação de fósforo na água ou nos sedimentos durante o inverno, onde será metabolizado ou levado para outras camadas oxidadas, disponibilizando-o para circulação biogênica;

- grande quantidade de polifenol em suas folhas, o que é de extrema importância para a formação de substâncias húmicas que, por sua vez, exercem fundamental função na formação de sedimentos e produção primária;

- fornecedora de detritos e energia orgânica, disponibilizando nutrientes e sedimentos para o ecossistema;

- estes detritos orgânicos são a ligação entre a produção primária e a secundária, representando uma grande fonte de energia para as espécies consumidoras;

- ao ser decomposto pelas populações microbiais, os detritos sofrem um enriquecimento protéico, gerando uma grande fonte nutricional para a cadeia alimentar.

Conclui-se que a presença da Spartina alterniflora contribui significativamente para o ambiente estuarino, tanto para componentes bióticos quanto para abióticos deste ecossistema. É vasto o número de estudos realizados sobre a gramínea em seus diversos aspectos, mas vale ressaltar a importância de pesquisas de longo prazo que relacionem a Spartina alterniflora aos ambientes de manguezais. 


\section{Capitulo 2 - Conectividade}

Para entendermos o conceito de conectividade, cabe primeiro entendermos as bases metodológicas que possibilitaram seu advento e o contexto em que essas bases foram desenvolvidas. Desta forma, facilita e aumenta-se o entendimento de sua origem, seus avanços e sua importância.

Serão tratadas aqui três diferentes abordagens que, de alguma forma, vieram beneficiar a idéia de conectividade, capacidade de movimento de espécies e conservação dos processos ecológicos (Benett, 2003). Cada abordagem será submetida à dois subtópicos, Argumentos e Benefícios, que mostrarão de forma simplificada e didática seus méritos e validades teóricos. $\mathrm{O}$ primeiro subtópico apresenta os conceitos presentes na abordagem e como se desenvolveram, e o segundo mostra o suporte gerado à favor da conectividade.

\section{História natural e manejo da vida selvagem}

\section{Argumentos}

As observações realizadas pelos pesquisadores de campo geraram um conhecimento empírico sobre espécies e comunidades, que são de grande importância e influência nos conceitos base do planejamento de áreas naturais (Bennet, 2003).

Observações dos movimentos migratórios; observações dos impactos de barreiras locais que influenciaram no fluxo e na mortalidade de espécies; observação do comportamento de animais e seus movimentos diários ou regulares, ajudaram a perceber a importância do movimento 
como processo ecológico (Bennet, 2003).

\section{Benefícios}

Tais conhecimentos empíricos beneficiaram o planejamento e manejo de áreas protegidas, à medida que:

- propiciaram às espécies a transposição de barreiras e a manutenção dos movimentos locais;

- ajudaram a manter os movimentos migratórios entre diferentes áreas geográficas;

- possibilitaram a recolonização de habitats através do aumento de dispersão e imigração (Bennet, 2003).

\section{Biogeografia Insular}

Argumentos

Desenvolvida por MacArthur e Wilson $(1963,1967)$, a teoria do equilíbrio em biogeografia insular resultou de constatações de ilhas que continham menos espécies do quem áreas continentais de relativo tamanho. A teoria propôs que o número de espécies de uma ilha tende a um nível de equilíbrio, determinado pela dinâmica entre colonização e extinção entre as residentes e as novas espécies da ilha (MacArthur \& Wilson, 1963, 1967 apud Bennet, 2003). A taxa de colonização é controlada, basicamente, pelo grau de isolamento da ilha em relação às áreas fontes do continente, enquanto a taxa de extinção é determinada, essencialmente, pela área da ilha. 


\section{Benefícios}

A analogia feita entre ilhas e áreas fragmentadas (topos de montanhas, lagos, reservas naturais, resquícios florestais, etc) influenciou no manejo, planejamento e desenho de áreas protegidas. $\mathrm{A}$ possibilidade de se determinar, teoricamente, um número de espécies em equilíbrio, bem como reduzir o isolamento e incentivar a colonização, proporcionou uma ajuda significativa à conservação natural.

A teoria de biogeografia insular beneficiou o movimento entre áreas fragmentadas ao incentivar a colonização através do não isolamento destas áreas.

\section{Ecologia da paisagem}

\section{Argumentos}

A ecologia da paisagem parte do princípio que toda a paisagem, seja em sua forma natural ou modificada pelo homem, é composta por um mosaico de diferentes tipos de habitat. Padrões espaciais compõem e influenciam os processos ecológicos presentes em tais mosaicos que, por sua vez, se alteram através do tempo (Forman \& Godron, 1986; Merriam, 1988; Hansson and Angelstam, 1991; Forman 1995; Hansson et al, 1995 apud Bennett, 2003).

Os movimentos das espécies, água, vento, bem como o fluxo de energia, matéria e nutrientes entre os mosaicos são essenciais para o entendimento da dinâmica das funções e processos ecológicos presentes na paisagem (Hobbs, 1993; Forman, 1995 apud Bennett, 2003). 


\section{Benefícios}

Para entendermos e conservarmos espécies e comunidades faz-se necessário entender a capacidade destas espécies de viverem dentro e entre os mosaicos da paisagem. O movimento das espécies entre os mosaicos configuram vetores de fluxo de energia, nutrientes e matéria que influencia a própria população e o próprio ambiente (Bennet, 2003).

Primeiros usos

Os primeiros estudos que trabalharam a idéia de conectividade partiram de análises e experiências baseadas na teoria de biogeografia de ilhas. Dados que mostravam a relação e a influência do tamanho de uma ilha, seu isolamento, taxas de imigração e colonização sobre o número de espécies, fizeram com que a conectividade fosse pensada e recomendada por alguns autores.

Preston (1962) escreve sobre as limitações das áreas de preservação, mostrando, através de seus estudos de distribuição canônica, a incapacidade de se ter uma réplica em escala menor da fauna e flora de uma área bem maior. E salienta a importância dos corredores contínuos entre áreas preservadas como único remédio para prevenir o isolamento da área. Ainda assim haveria um emprobecimento da biodiversidade em uma escala nacional pela redução de áreas naturais.

Willis (1974) ao estudar a população de pássaros na ilha de Barro Colorado, Panamá, concluiu que a preservação de áreas naturais seria mais eficiente se não fossem isoladas ou cercadas por usos antrópicos, mas pelo contrário, se fossem ligadas por "zonas de corredores" (Figura 5). 
Diamond (1975), sobre o desenho de áreas protegidas, ressaltou a importância de se conectar várias reservas separadas através de faixas de habitats protegidos, uma vez que estes conectores podem aumentar significativamente o objetivo de conservação. Espécies das áreas protegidas não teriam que atravessar vastas áreas de habitats impróprios, especialmente nos casos de espécies sedentárias e com restritas preferências de habitats.

\section{Conectividade}

Taylor et al. (1993) chegou ao conceito de conectividade mais aceito e utilizado no âmbito das ciências naturais. Ao analisar o trabalho de Dunning et al. (1992) sobre os processos ecológicos presentes em uma paisagem, Taylor o complementou ao mostrar a importância do movimento como componente da estrutura da paisagem (Figuras 6 e 7). A habilidade de uma espécie de utilizar dos recursos de uma área está totalmente relacionada à sua habilidade de chegar até esta área. O que determina esta habilidade não é somente a distância, mas também a natureza biofísica da rota que será utilizada, além do comportamento da espécie. Alguns caminhos facilitam, ou não impedem o movimento entre áreas; outros obstruem, em diferentes níveis, o movimento das espécies. Devido à grande importância do movimento das espécies, conclui-se uma terceira medida de estrutura da paisagem, denominada 'conectividade'. 


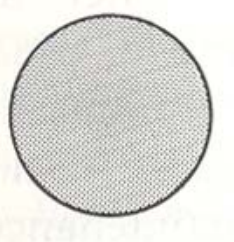

A
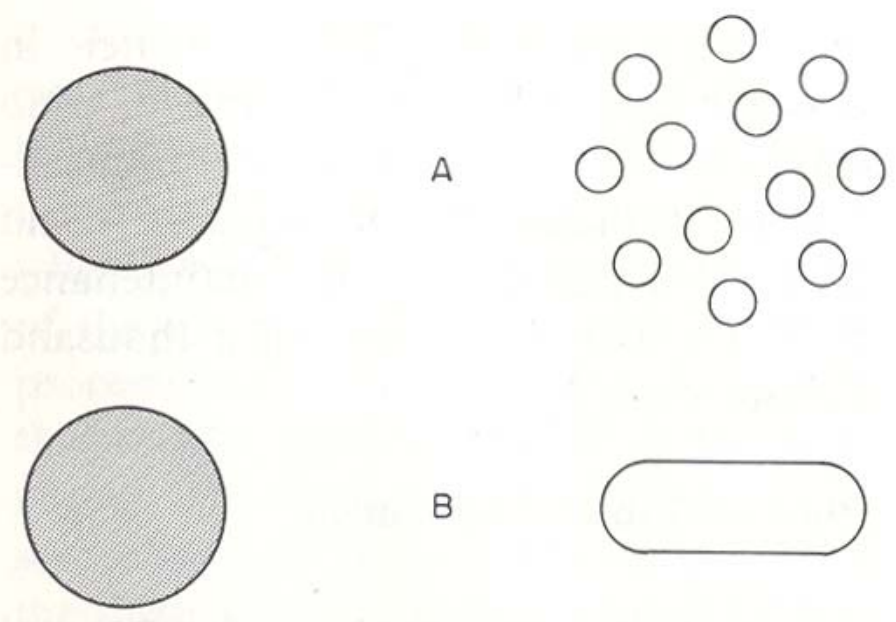

B

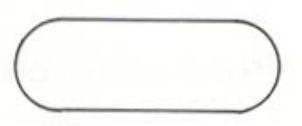

C

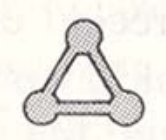

D

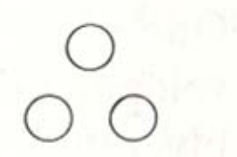

Figura 5: Regras geométricas para o desenho de reservas naturais, baseadas na teoria biogeográfica atual. Os desenhos da esquerda resultam, em cada caso, em uma taxa de extinção espontânea menor do que os da direita. Tanto as figuras da esquerda quanto as da direita têm a mesma área total e representam reservas de ambientes homogêneos. A: uma reserva contínua é melhor do que uma fragmentada, devido ao efeito de área e distância. B: um desenho circular é melhor, devido ao efeito de borda (MacArthur \& Wilson, 1967, pp. 115-116 e figura 37). C: fragmentos agregados são melhores do que aqueles dispostos linearmente, devido ao efeito de distância. D: se a reserva necessita ser dividida, a extinção será menor quando os fragmentos forem conectados por corredores de habitat natural, não importando a largura dos corredores (Willis, 1974). Outro princípio, não incorporado neste esquema, é o de que, independente do desenho da reserva, a taxa de extinção pode ser diminuída se reservas similares estiverem próximas ${ }^{5}$.

5 Extraído de Wilson \& Willis (1975) Applied Biogeography. In: Cody, M. L. \& Diamond, J. M. (ed) Ecology and evolution of communities. Belknap Press of Harvard University Press: Cambridge, Massachusetts and London: England. 
"Conectividade da paisagem é o grau em que a paisagem facilita ou impede o movimento entre áreas fontes" (Taylor et al., 1993).

Forman (1995) trabalhou conectividade como medida de para as conexões entre corredores, redes e matriz. Quanto menor o número de descontinuidades, maior a conectividade estrutural, o que não define ou garante uma conectividade comportamental.

Esses dois componentes, estrutura e comportamento, definem o potencial de conectividade para uma área, espécie, comunidade ou processo ecológico (Bennett, 1990 apud Bennett, 2003).

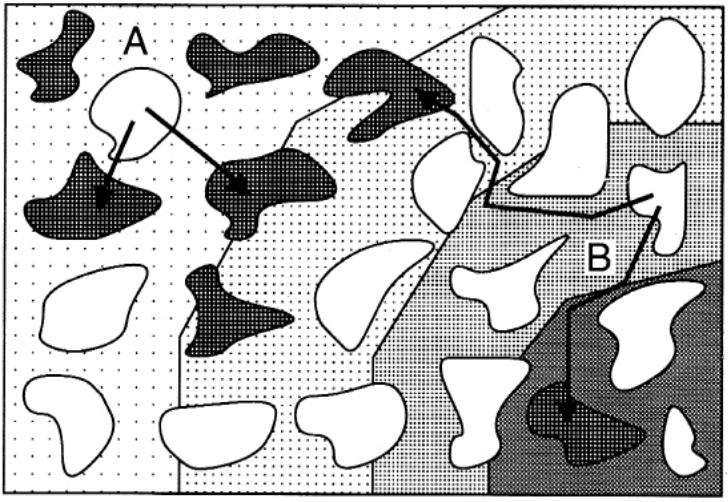

Figura 6: Complementação de paisagem. Conectividade da paisagem baseia-se em um mosaico de fragmentos. Áreas claras e escuras possuem diferentes tipos de recursos para os animais. Áreas mais escuras possuem maior conectividade. Animais na área B podem acessar fragmentos mais facilmente (setas) complementando assim suas necessidades por recursos (Taylor et al., 1993).

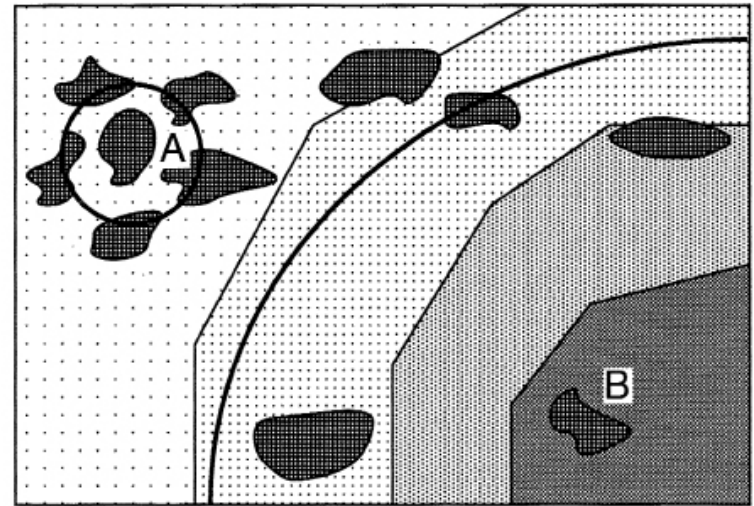

Figura 7: Suplementação de paisagem. Conectividade da paisagem baseia-se em um mosaico de fragmentos. As áreas mais escuras possuem maior conectividade. Animais na área $\mathrm{B}$ podem acessar outros fragmentos mais facilmente do que na área A (áreas dentro do círculo) complementando assim suas necessidades por recursos (Taylor et al., 1993). 
O componente estrutural da conectividade é determinado pelo arranjo espacial dos diversos tipos habitats presentes na paisagem. Está intimamente relacionada à continuidade de habitats adequados, ao tamanho e quantidade de lacunas entre os fragmentos, à distância a ser percorrida pelas espécies, presença, ou não, de caminhos alternativos (Bennett, 1990 apud Bennett, 2003).

O componente comportamental da conectividade está relacionado às reações das espécies ao ambiente físico que ela se insere. É influenciado pela escala espacial e temporal em que ocorre o movimento, sua percepção da paisagem, necessidade de recursos, tolerância a habitats transformados, estágio da vida em que a espécie se encontra, resposta à predadores e competidores. Desta forma, espécies que habitam uma mesma área da paisagem, podem experienciar diferentes níveis de conectividade (Bennett, 2003).

A análise desses dois componentes abre espaço para uma discussão sobre o que é, em termos práticos, realmente conectividade. Amplia-se o escopo de entendimento da conectividade: os corredores, em suas diversas formas, que durante muito tempo vêm sendo colocado em uso, deixam de ser os únicos meios de se obter conexão. Não é objetivo desta discussão subestimar os valores e sucessos dos corredores ecológicos, mas sim aumentar a forma de se entender e trabalhar conectividade, bem como instigar o conhecimento. 


\section{Conexões e conectores}

Diferentes tipos de corredores existem e são criados, tanto pela natureza quanto pelo homem. Cursos d'água, trilhas de animais, o topo de uma encosta, estradas, linhas de energia, canais, todos eles são, com suas diferenças, formas de corredores de conexão.

Os corredores são faixas que diferem do seu entorno permeando a paisagem. Corredores de vegetação exercem importantes funções e atendem diferentes objetivos (Bennett, 2003): (a) corredores protegem a biodiversidade da vegetação ripária, espécies raras e ameaçadas, além de rotas de dispersão; (b) corredores ajudam o gerenciamento de água, controle de enchentes e sedimentação, capacidade de reservatório, ajudam na manutenção de peixes e da pesca; (c) faixas lineares podem colaborar na produção agroflorestal atuando como quebra-ventos, controlando erosão dos solos, fornecendo madeira e prevenindo contra desertificação; (d) os corredores podem servir como área de recreação e prática de esportes; (e) cinturões verdes podem atuar como fator de coesão entre comunidade e cultura, criando identidade e diversidade cultural; (f) corredores são rotas de dispersão para espécies isoladas em áreas de preservação e faixas de vegetação litorânea.

Os corredores podem se diferenciar quanto à sua origem, solicitando manejos adequados de acordo com seu propósito (Forman \& Godron, 1986):

Corredores naturais, geralmente acompanhando as características da paisagem, seguem caminhos da topografia, bem como os cursos d'água associados à vegetação ripária; 
Corredores remanescentes, são o resultado da alteração ou distúrbio do seu entorno, podem ser representados por matas ao longo de estradas, áreas não utilizadas pela atividade madereira, ou qualquer outro processo que deixe remanescentes lineares;

Corredores restaurados, resultado da recuperação de áreas antes degradadas, buscando seu estado natural;

Corredores plantados, como cercas vivas, quebra-ventos, cinturões, geralmente compostos por espécies não nativas, com um propósito antrópico evidente;

Corredores de distúrbio, gerados através de construção de estradas, linhas de energia e transmissão, etc., apresentando uma linha de distúrbio que difere do seu entorno.

Alguns tipos de corredores surgiram paralelamente às atividades agriculturais, usados como área de proteção, delineamento de fronteiras, como estoque ou área de expulsão de herbívoros, entre outros.

Cercas vivas ${ }^{6}$ são um exemplo de conectividade linear que ocorrem, principalmente, em áreas rurais. Apresentam variações diversas quanto à estrutura, composição florística e origem (Bennett, 2003). Geralmente são de origem antrópica, compostas, em sua grande maioria, de arbustos e pequenas árvores, mas podendo também conter grandes árvores.

As cercas vivas exercem função de conectores entre áreas naturais e semi-naturais em ambientes rurais. Estão fortemente associadas à agricultura e sua composição e estrutura estão

6 Tradução livre adotada para "Hedgerows". 
intimamente relacionados às plantações ou pastos adjacentes (Forman and Baudry, 1984).

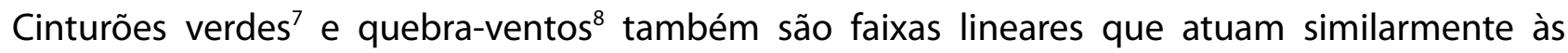
cercas vivas. Também criados pelo homem, podem exercer diversas funções e atingir diferentes objetivos: proteção de ventos, diminuir erosão, fonte de madeira, habitats e estética (Forman \& Baudry, 1984).

A zona ripária é formada pela vegetação adjacente aos cursos d'água (mata ciliar), apresentando características estruturais e florísticas diferentes do seu entorno. A vegetação ripariana destacase como um rico habitat para fauna (Figura 8) (Murray \& Stauffer, 1995 apud Bennett, 2003). Essa grande riqueza de habitats se deve, em parte, pela inteface de contato entre ambientes terrestres e aquáticos, que está sujeita a inundações, diferentes níveis de água, piscinas isoladas, padrões sucessionais de vegetação, o que contribui para uma diversidade de habitats e oportunidades para a fauna (Bennett, 2003). A esse fator, também associa-se a ótima fertilidade dos solos aluviais, o que favorece um maior volume e diversidade estrutural da vegetação, e a possibilidade de ocorrência de ecótonos entre a vegetação ripariana e a vegetação das partes mais altas.

A zona ripária também possui importante função na regulação hidrológica, na filtragem de sedimentos e nutrientes, estabilização das margens, regulação da temperatura da água e, consequentemente, na produtividade do sistema (Bennett, 2003).

As estradas de rodagem, criadas para transporte e integração de um país, representam um grande sistema linear que, com a presença de vegetação lateral, podem ser grandes reservas da vida selvagem. Na Inglaterra, estima-se que a vegetação de estradas somam um total de 212.000 
ha de reservas (Way, 1977), e nos Estados Unidos este número pode alcançar 8.1 milhões de hectares (Adams \& Geis, 1983). A vegetação ao longo das estradas possuem, se bem implantadas e manejadas, um grande potencial de conectividade estrutural.

Fragmentos de áreas preservadas próximos uns dos outros podem agir como conectores através de uma sequência de movimentos entre as áreas. Os "stepping stones" são adequados para aumentar a conectividade em paisagens já alteradas, principalmente para espécies tolerantes e capazes de realizar movimentos entre áreas fragmentadas.

A conectividade estrutural, obtida através de meios físicos, por sua forma mais palpável e por seus benefícios próprios à preservação da biodiversidade, despertou interesse e cativou diversas esferas que trabalham com conservação e planejamento. O grande interesse pelos corredores de conectividade e seus diversos usos, gerou também debates e críticas sobre o conceito de conectividade, os diferentes meios e escalas de obtê-la. 

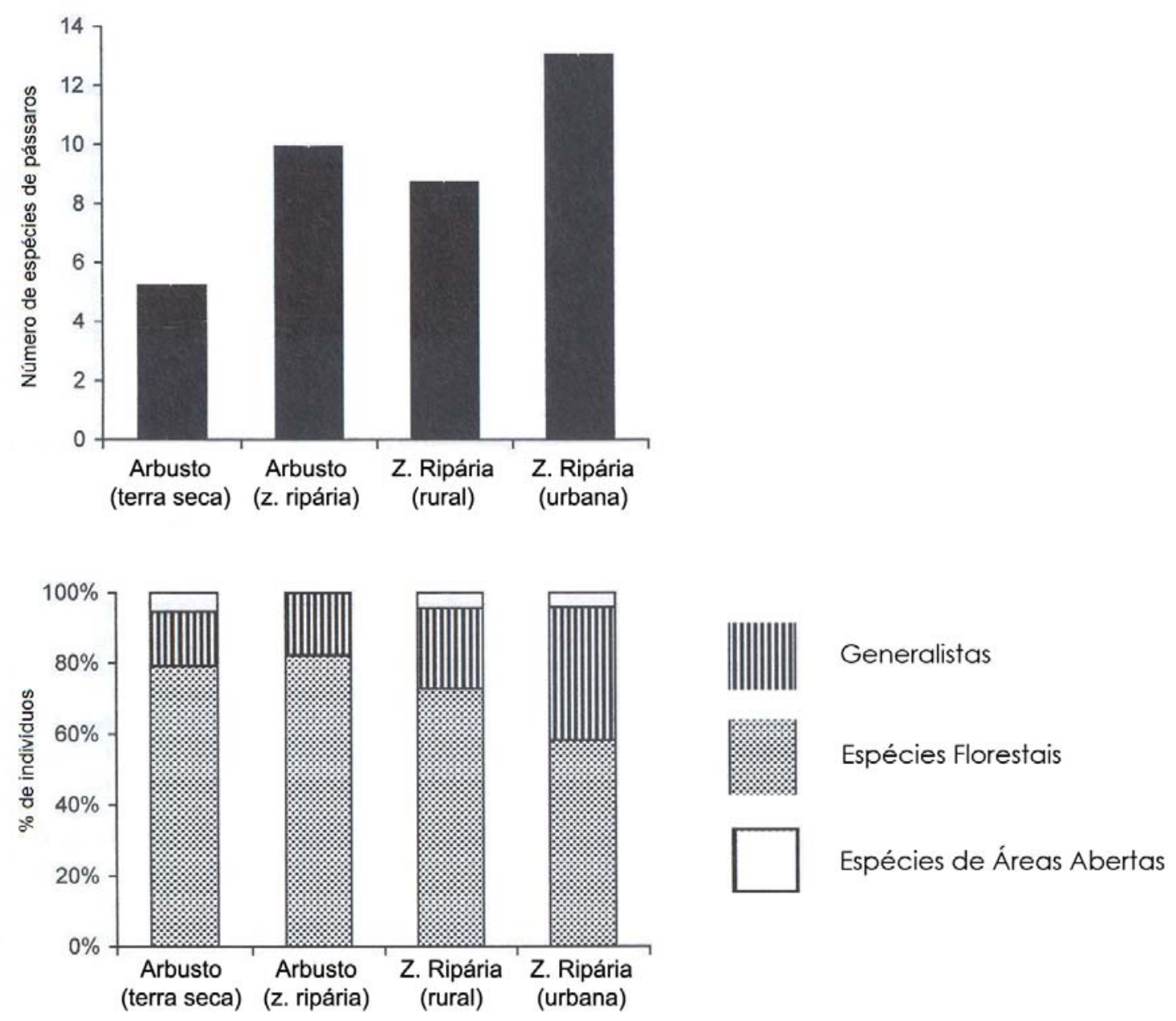

Figura 8: Ocorrência de espécies de pássaros no inverno em habitats riparianos próximos à Brisbane, Queensland, Australia. (a) Comparação da riqueza de espécies entre arbustos em terras secas, arbustos em zona ripária, faixas de vegetação ripária remanescentes em áreas rurais e faixas de vegetação ripária em áreas urbanas. (b) Porcentagem média de indivíduos por diferentes tipos de cobertura vegetal (Bennet, 2003). 


\section{Corredores e Conectividade}

Os corredores ecológicos são conceitos bem sucedidos, técnicas práticas com respostas diretas para problemas reais. "Uma solução visível para um problema visível" (Bennett, 2003). Desta forma, os corredores ganharam grande aceitação diante aos problemas da conservação da biodiversidade, mas, ao mesmo tempo, ofuscaram outros meios de se entender e obter conectividade.

As críticas e o ceticismo podem ser agrupados em três pontos gerais (Noss, 1987; Simberloff \& Cox, 1987; Harris \& Gallagher, 1989; Harris \& Scheck, 1991; Nicholls \& Margules, 1991; Stolzenburg, 1991; Hobbs, 1992; Simberloff et al., 1992; Andrews, 1993; Bonner, 1994; Hess, 1994 apud Bennett, 2003):

- se as evidências científicas são suficientes para demonstrar os possíveis benefícios de conservação dos corredores;

- se os possíveis efeitos negativos dos corredores podem superar o seu valor de conservação;

- $\quad$ se os corredores são apresentam um bom custo-benefício em comparação com outros modos de conservar os recursos.

Além dos conectores lineares, outras formas de conectar habitas, como "stepping stones", mosaico de áreas preservadas; outras formas de movimento, como movimentos migratórios e movimentos diários; outras formas de perceber a conectividade, como processos ecológicos presentes dentro e entre habitats. 
Há poucas dúvidas que o movimento de animais e plantas, e o fluxo do vento, água, materiais, nutrientes, energia e biota entre habitats é fundamental para o funcionamento natural do ecossistem (Forman, 1995). E pergunta que faz-se necessária é:

Qual o padrão mais eficiente em uma dada paisagem que assegura conectividade ecológica para espécies, comunidades e processos ecológicos? (Bennett, 2003).

E mais além, quais os processos ecológicos existentes na paisagem nos mostram a conectividade natural entre habitats e ecossistemas?

\section{Movimento}

O conceito de conectividade está intrinsicamente relacionado às formas de movimento e dispersão das espécies. Movimentos diários ou sazonais buscando atender suas necessidades biológicas e comportamentais, ou dispersão, procurando aumentar sua área de distribuição, através de movimentos à partir de seu local de origem (Noss, 1991).

Uma vez que diferentes espécies possuem diferentes formas de se movimentarem e dispersarem, conectividade pode ser obtida, ou obstruída, de diferentes maneiras de acordo com cada espécie. Espécies voadoras possuem maior mobilidade que espécies terrestres. Ainda assim, algumas espécies de pássaros possuem barreiras psicológicas para cruzar ambientes aquáticos (Noss, 1991). Plantas cuja dispersão é dada através de pássaros ou vento podem ser bastante móveis, enquanto aquelas dependentes de formigas não terão uma dispersão tão ampla. Um corredor para uma espécie pode ser uma barreira para outra (Noss, 1991). 
As particularidades de cada espécie geram diferenças físicas, biológicas, comportamentais, diferenças de movimento e dispersão, etc., ressaltando a importância de se gerar uma conectividade que abranja e otimize uma grande variedade de habitats e uma ampla gama de espécies. Pensar a conectividade de uma forma mais ampla, envolvendo conexões de espécies, comunidades, processos ecológicos e escalas espaciais e temporais múltiplas (Noss, 1991).

\section{Múltiplas Escalas}

Uma vez clara a complexidade do mundo natural e todos os seus processos biológicos, fica também evidente a necessidade de conservação da biodiversidade em toda sua integridade, abrangendo as maiores e possíveis escalas espacial e temporal.

\section{Escala Espacial}

As diferenças de movimento e disperção entre as espécies, deixa óbvio as diversas escalas espaciais presentes em uma mesma paisagem. Espécies voadoras tendem a ter uma maior mobilidade do que as não voadoras; animais carnívoros geralmente são menos sedentários do que herbívoros; grandes mamíferos terrestres possuem uma percepção de tamanho de escala totalmente diferente de insetos também terrestres. A diferença espacial escalar pode ocorrer mesmo ao analisar uma única espécie, levando-se em conta os diferentes estágios de sua vida: sapos iniciam sua vida exclusivamente em ambientes aquáticos, depois passando a ocupar também ambientes terrestres (Bennett, 2003). 
Não existe uma solução geral para se manter a conectividade para todas as espécies. Diferentes qualidades, escalas e tipos de conexões são necessários para toda a diversidade das espécies e processos ecológicos.

\section{Escala temporal}

Paisagens, seus ecossitemas e habitats não são estáticos, mas mudam através do tempo. Essas mudanças podem resultar de processos naturais ou de distúrbios causados pela ação antrópica. Em ambas mudanças, pode haver alterações na estrutura, nos processos ecológicos, na dinâmica natural e, consequentemente, na disponibilidade de recursos para as espécies (Bennett, 2003).

Dinâmica dentro de uma população também pode alterar com o decorrer do tempo. O número de indivíduos pode aumentar com as taxas de imigração, ou diminuir devido à extinção. Esta flutuação de densidade de uma espécie pode influenciar outras, interferindo nos processos ecológicos que garantem conexões entre habitats.

Trabalhar com escalas temporal e espacial, possibilita vizualizar a conectividade no seu sentido mais amplo, levando-se enconta não somente a estrutura da paisagem, mas a dinâmica natural e suas conexões.

As discussões sobre conectividade que permeiam as pesquisas e projetos de planejamento e manejo da vida silvestre, em sua grande maioria, estão calcados em como se estabelecer corredores. Deixa-se negligenciado o importante fato de que conectividade é um elemento natural e já existente na paisagem. 
A ação humana, em suas diversas formas, pode destruir ou criar barreiras, dificultando ou impossibilitando a conectividade antes existente. O que se faz extremamente necessário é restaurar ou manter corredores ou qual seja a forma mais adequada de conectividade, e não "estabelecê-la".

Pensar a conectividade de uma forma mais ampla e abrangente proporciona um entendimento mais completo da dinâmica da natureza, e nos dá a certeza de que ainda há muito o que pesquisar e o incentivo para continuarmos pesquisando. 


\section{Capitulo 3 - Sedimentação e formação das ilhas do sistema lagunar}

Pensar a conectividade através de um estudo insular e adotar uma espécia vegetal como principal indicador e objeto de estudo, fez com que o trabalho compreendesse um conceito mais abrangente de conectividade.

A idéia usual de ilhas como terras isoladas geograficamente e a ausência de mobilidade do indivíduo vegetal podem gerar, em um primeiro momento, um pensamento de inexistência de relações efetivas entre matéria, fluxo e energia entre as áreas estudadas.

Os cursos d'água vêm, neste contexto, fazer a conexão entre as ilhas, dando movimento aos sedimentos e nutrientes de diversas origens e criando um terceiro ambiente de grande fluxo e troca.

Em uma região lagunar lagunar repleta de manguezais bem desenvolvidos, a abundância dos nutrientes e sedimentos realça ainda mais essa idéia de conectividade entre os bosques das ilhas. A composição dos sedimentos, a natureza dos nutrientes e a origem e formação do embasamento da região são fundamentais na caracterização desta conectividade.

O Morro de São João, com 120 metros de altura (Kutner, 1962) e composto por rochas alcalinas (Freitas, 1947), é a única elevação da Ilha de Cananéia. Todo o restante da ilha é constituído por sedimentos quaternários.

Suguio \& Martin (1978) descrevem a Ilha Comprida como uma barreira quaternária separada do continente pelos mares Pequeno e de Cananéia. Uma longa e estreita ilha, com $70 \mathrm{~km}$ de 
extensão e máximo de $5 \mathrm{~km}$ de largura, e altitudes baixas que alcançam os 7 metros. A única exceção é o Morrete, com 42 metros de rochas alcalinas.

Um afloramento cristalino submerso mostra-se como a ligação entre o Morrete e o Morro de São João em Cananéia, localizados na parte sul de suas respectivas ilhas (Suguio \& Martin, 1978).

A caracterização geológica da área de estudo revela a recente geomorfologia lagunar desta região. Essa grande planície costeira sedimentar remete aos depósitos sedimentares do cenozóico. Suguio e Petri (1973) caracterizaram esta estigrafia em quatro estádios:

\section{a) Sequência 1}

118 metros de espessura;

areias e areias conglomeráticas com níveis argilosos;

recobre, provavelmente, o embasamento cristalino.

b) Sequência 2

- argilas sílticas ricas em diatomáceas e pobres em foraminíferos bem preservados;

- indicativa de ambiente transicional.

c) Sequência 3

- 7 a 12 metros de espessura;

- $\quad$ areias sílticas com abundantes foraminíferos bem preservados.

c) Sequência 4

- 20 a 30 metros de espessura; 
- areia fina a muito fina bem selecionada e com boa distribuição;

- fornecedora de sedimentos para as praias atuais.

O desenvolvimento geomorfológico desta planície sedimentar está intimamente ligado às fases transgressivas quaternárias. Evidências sedimentológicas, biológicas e pré-históricas, identificadas através de estudos de mapeamentos sistemáticos e datações de amostras pelo método do radiocarbono (Suguio \& Tessler, 1992), comprovam os diferentes paleoníveis marinhos da costa brasileira. Tais transgressões foram processos atuantes muito importantes na evolução da região lagunar de Cananéia-Iguape e outras planícies costeiras brasileiras.

Dentre os diferentes cenários de níveis marinhos, o paleonível marinho mais alto de 120.000 anos A.P. é conhecido, no litoral paulista, como Transgressão Cananéia (Suguio \& Martin, 1978) ou, nacionalmente, como Penúltima Transgressão (Bittencourt et al., 1979).

A Transgressão Cananéia exerceu papel predominante nos depósitos sedimentares da Formação Cananéia (Suguio \& Petri, 1973). Os alinhamentos das cristas praiais, ao analisadas por fotos aéreas, revelam também a existência de uma fase regressiva. A parte argilosa basal da Formação Cananéia, primeiro depositada em águas salobras e posteriormente em ambientes marinhos demostram a fase trangressiva (Suguio \& Tessler, 1992).

Além da Transgressão Cananéia, ocorreram depósitos arenosos menos extensos durante a Transgressão Santos e também, nas margens dos canais lagunares, depósitos de manguezal bem desenvolvidos.

Suguio e Tessler (1992) descrevem a evolução da planície costeira entre a Ilha do Cardoso e a 
Juréia em cinco estádios:

Primeiro estádio - no ápice da Transgressão Cananéia, o nível do mar, provavelmente, atingiu a base da Serra do Mar, depositando argilas transicionais e marinhas da Formação Cananéia;

Segundo estádio - já na fase regressiva, depósitos de cristas praiais recobriram os depósitos arenosos da Formação Cananéia;

Terceiro estádio - há cerca de 18.000 anos A.P., o nível do mar esteve 110 metros abaixo do atual, o que possibilitou aos rios da recente planície costeira erodir os sedimentos arenosos da Formação Cananéia;

Quarto estádio - o próximo evento transgressivo é caracterizado por um rápido aumento do nível do mar que alagou as áreas erodidas pelos rios, formando um grande sistema lagunar;

Quinto estádio - o retorno do nível do mar para o atual gerou depósitos holocênicos de cristas praiais.

A gênese e evolução geomorfológica da região lagunar Cananéia-lguape está intimamente ligada aos eventos transgressivos e regressivos do quaternário, aos processos hidrodinâmicos atuantes na costa e à circulação atmosférica da parte sul da América do Sul (Suguio \& Petri, 1973). Esse processo evolutivo resultou em uma planície costeira semi-confinada, apresentando tendências típicas ao assoreamento e feições sedimentares de deposição (Besnard, 1950).

O movimento de marés e as descargas de água doce exercem forte influência na dinâmica 
geomorfológica do sistema, influindo na distribuição dos sedimentos de fundo, norteando os fenômenos erosivos e as feições de deposição (Tessler, 1982; Tessler \& Furtado, 1983).

A hidrodinâmica dos canais lagunares do sistema Cananéia-Iguape possui comportamentos já estudados e conhecidos. Bancos de areia, esporões e ilhas são feições sedimentares freqüentes no Mar de Cananéia e Cubatão e no Mar Pequeno (Cunha-Lignon, 2001). Tessler e Furtado (1983) citam as ilhas de Pai Matos, Boqueirão, Garça e Furadinho, todas recobertas por manguezais, como pontos de deposição de sedimentos.

O mar Pequeno é o menos meandrante dos canais do sistema Cananéia-Iguape. No seu início, ao norte da Ilha de Cananéia, no encontro dos mares Cubatão e de Cananéia, apresenta um canal de circulação mais profundo, pouco meandrante e com diversas ilhas sedimentares. Na sua parte mais setentrional, da pedra do Tombo à Barra de Icapara, o canal se apresenta mais retilíneo e menos ilhas sedimentares (Tessler \& Furtado, 1983). 


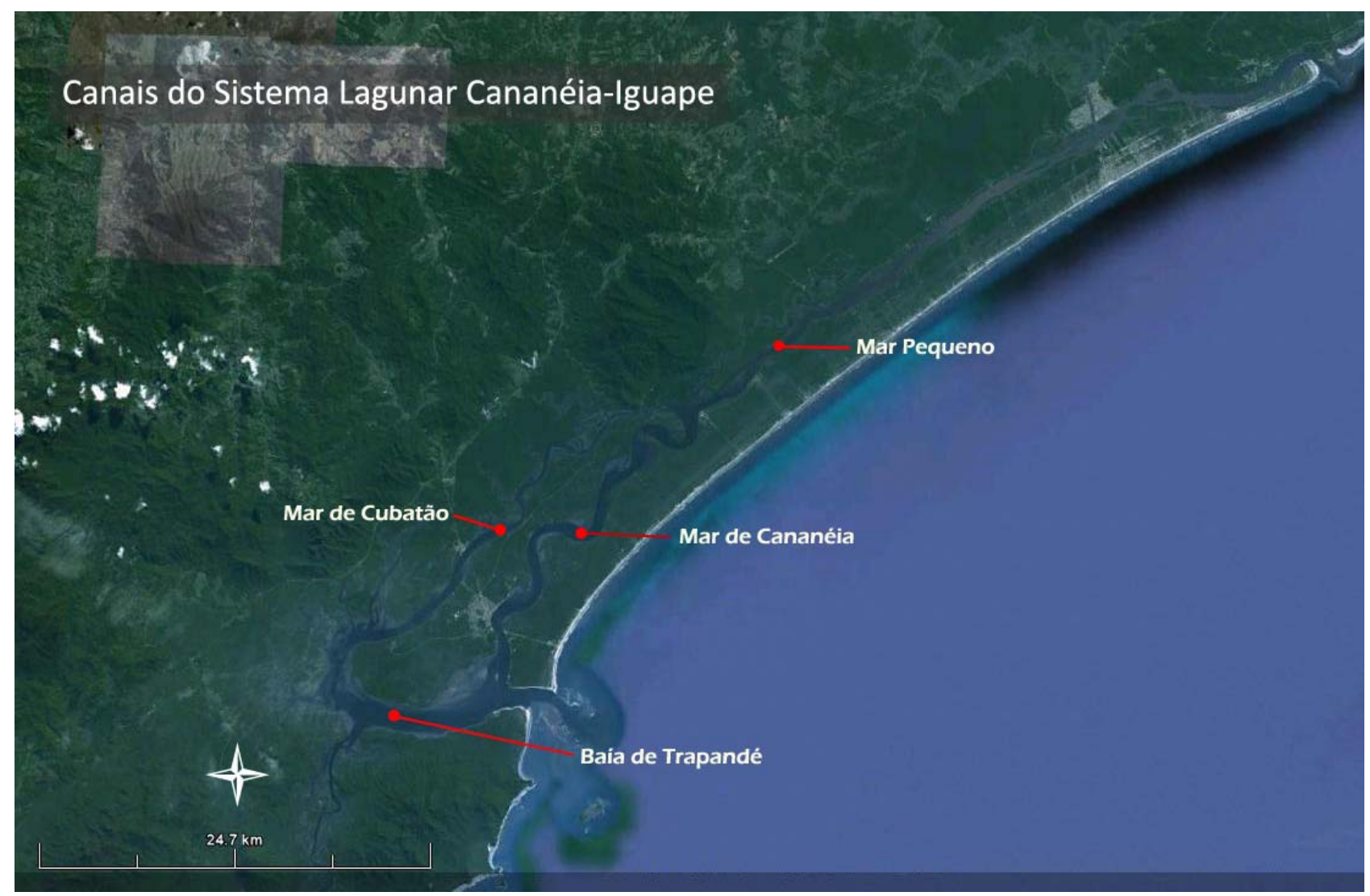

Figura 9. Mapa esquemático dos canais lagunares do sistema Cananéia-Iguape.

O mar de Cubatão, o mais estreito do sistema, possui profundidades maiores que 5 metros nos pontos de confluência com outros canais (mar de Cananéia e baía de Trapandé). Pouco meandrante e com poucas ilhas sedimentares (Tessler \& Furtado, op cit).

O mar de Cananéia, área de estudo deste trabalho, é o mais meandrante e mais profundo dos canais do sistema. Nele encontram-se várias feições de deposição como as diversas ilhas sedimentares (Pai Matos, Boqueirão, Garça, Furadinho, etc) e bancos de areia (Tessler \& Furtado, op cit).

Tessler e Furtado (op cit), através de cartas náuticas e fotografias aéreas, concluíram que as feições de deposição do mar de Cananéia possuem um sentido preferencial de crescimento, 
uma tendência ligada a um fluxo unidirecional que se originam à partir das correntes de maré. $\mathrm{O}$ alongamento das feições de deposição em direção à barra de Cananéia evidencia este predomínio (Figuras 10, 11 e 12).

As feições de deposição, bem como a maior parte do padrão hidrodinâmico do sistema, estão forte e intimamente ligadas às correntes geradas pelas oscilações da maré (Tessler \& Souza, 1998). A difusão das ondas de maré têm início na baía de Trapandé, na desembocadura situada ao sul da cidade de Cananéia (Miniussi, 1959).

Na enchente, as ondas de maré adentram o sistema pela barra de Cananéia, no limite sul da ilha Comprida, e se dividem pelos canais que circundam a ilha de Cananéia, os mares de Cubatão e Cananéia. No limite norte da ilha de Cananéia os canais retomam o fluxo único pelo mar Pequeno, em direção à outra entrada de correntes de maré, na desembocadura de Icapara. O encontro dos fluxos contrários, ambos de enchente, é o fenômeno hidrodinâmico conhecido como "tombo das águas" (Tessler \& Souza, 1998). Na maré vazante os fluxos se invertem rumo às ligações com o oceano. 


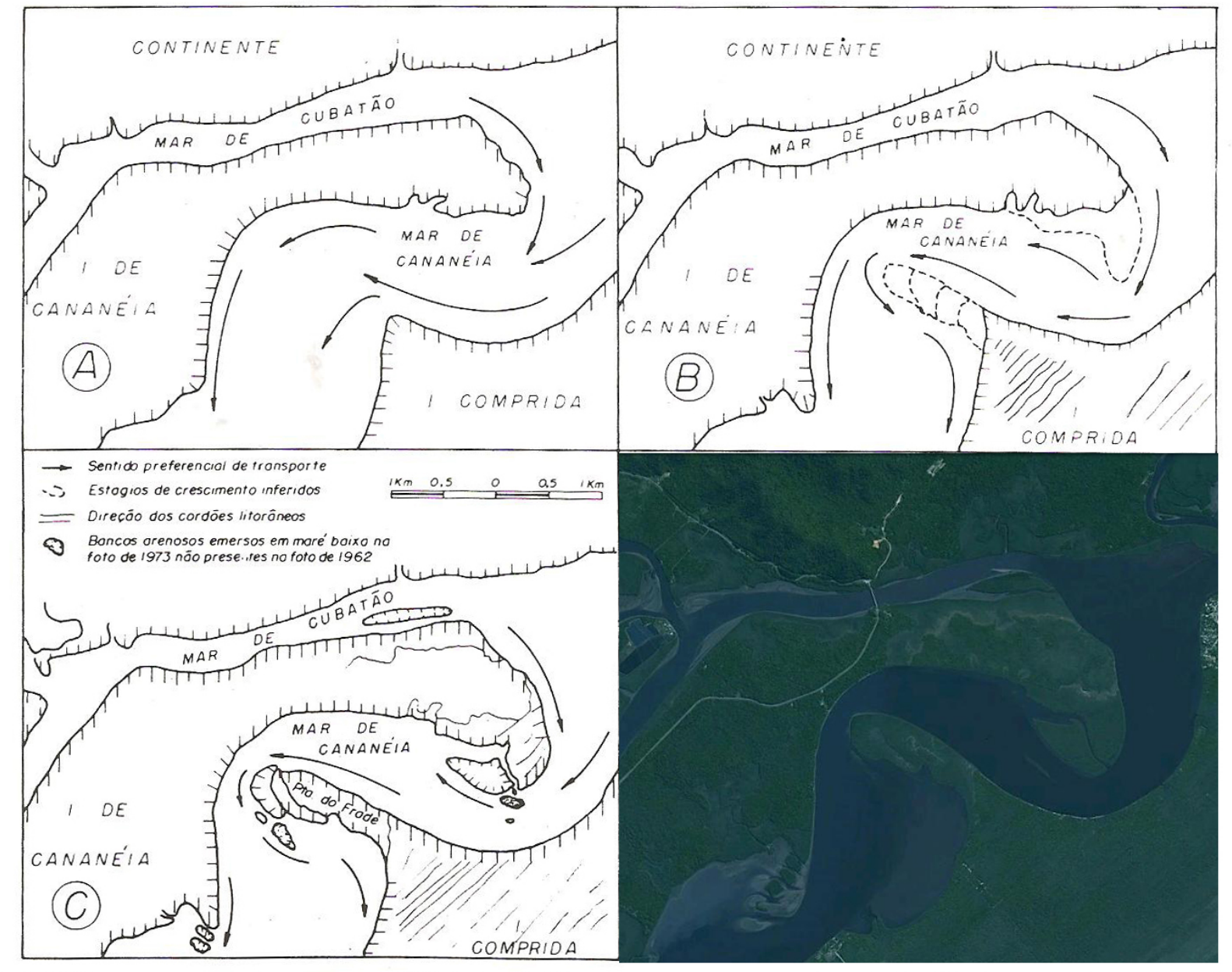

Figura 10: Comparação esquemática da evolução da Ponta do Frade: a) estágio preliminar do esporão; b) fase intermediária; c) configuração atual da Ponta do Frade (Tessler \& Furtado, 1983). Imagem de satélite atual (Google Earth, 2010).

Tessler e Furtado (op.cit), à partir de cartas náuticas, batimétricas, fotografias aéreas e estações de medição, verificaram que a velocidade máxima das correntes de maré em todo o sistema foi de 1,2 m/s, no mar de Cananéia no período de vazante. Os mares de Cubatão e de Iguape apresentaram valores semelhantes para as velocidades de fundo e superfície, enquanto que no mar de Cananéia a discrepância foi bastante acentuada, especialmente na vazante. 


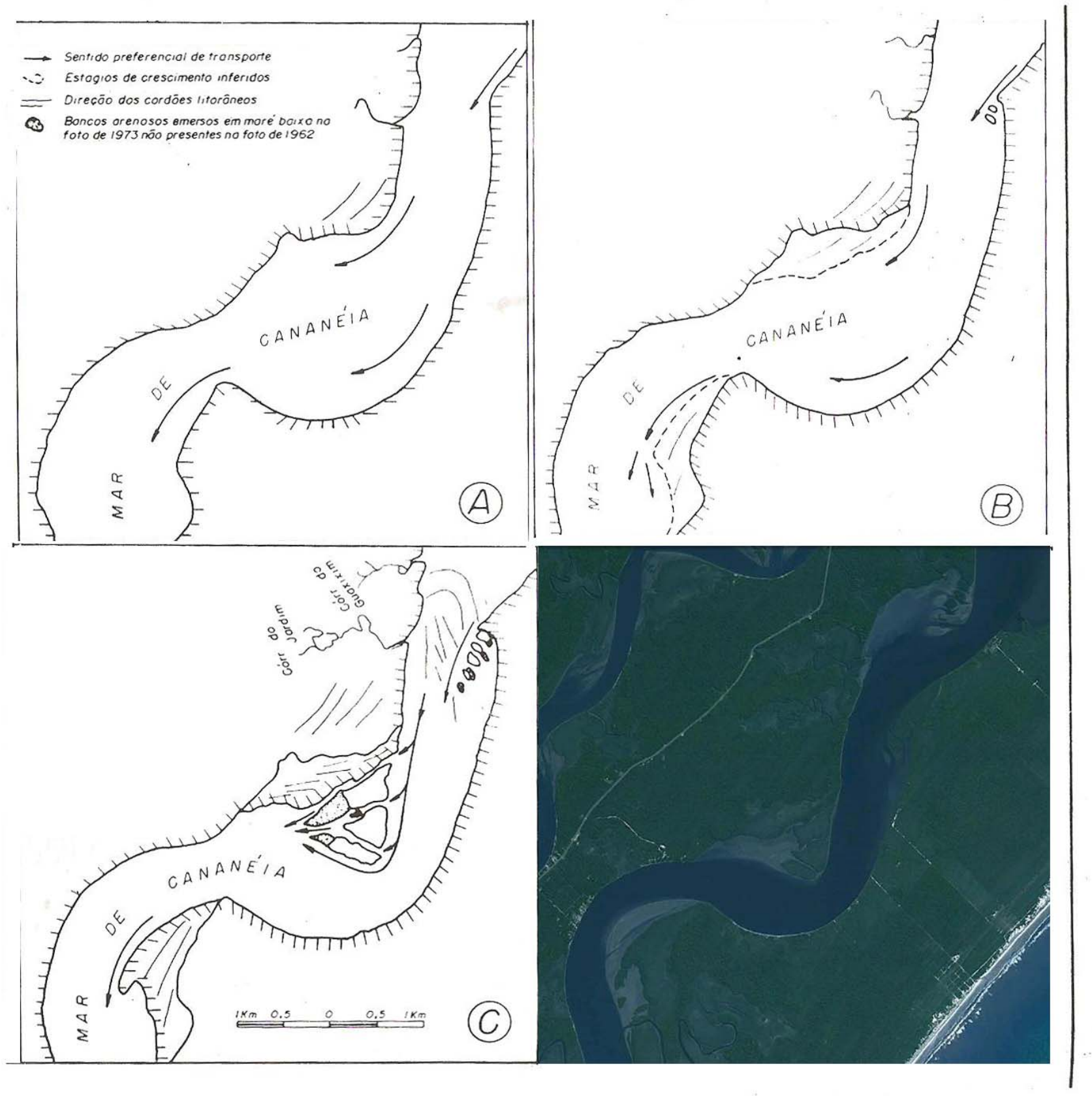

Figura 11: Comparação esquemática da evolução da ilha do Boqueirão: a) feições de deposição da ilha de Cananéia que darão as configurações da ilha do Boqueirão; b) banco de areia incorporado pela ilha de Cananéia; c) configuração atual da ilha do Boqueirão (Tessler \& Furtado, 1983). Imagem de satélite atual (Google Earth, 2010) - no detalhe, área da Figura Y . 

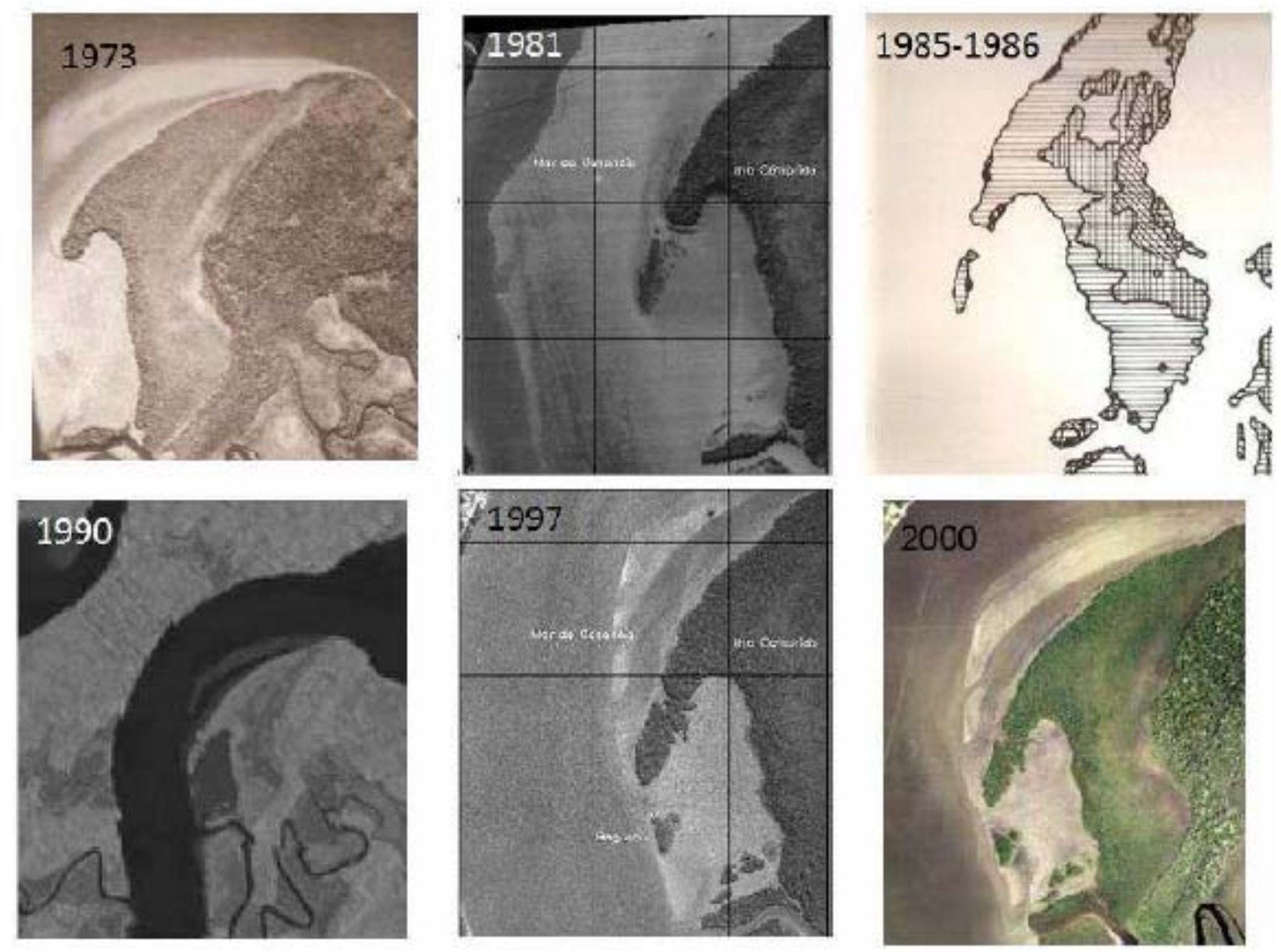

Figura 12: Fotografias aéreas e imagens de satélite, em diferentes escalas temporais e espaciais, da ilha de Baguaçu entre 1973 e 2000 (Hertz, 1991; Cunha-Lignon, 2002).

Apesar da ocorrência de correntes de direções alternadas nas enchentes e vazantes, e com sentidos opostos de deslocamento nas camadas de superfície e fundo, as maiores velocidades marés de vazante, tanto de fundo quanto de superfície, corroboram o sentido preferencial das feições de deposição deposição. 


\section{Análises de Campo}

Norteado pelos objetivos a serem alcançados, os trabalhos de campo foram delimitados de forma que otimizassem todo o processo sem comprometer os resultados esperados. A definição da área de coleta partiu deste pressuposto somado ao escopo do projeto, o que foi dando forma ao trabalho.

A princípio, pensou-se coletar todos os bancos de Spartina margeando a costa da Ilha de Cananéia, porém, devido à sua grande extensão, requereria mais tempo do que o previsto para a realização da dissertação. Além disso, sustentado por uma base biogeográfica insular, nada mais sábio e necessário do que trabalhar a relação entre ilhas, e não a singularidade.

Da mesma forma que se acrescentou uma ilha, o continente e o oceano não foram incluídos. $\mathrm{O}$ objetivo foi obter resultados da face de contato entre a llha de Cananéia e llha Comprida.

Partindo da Base do Instituto Oceanográfico da USP (limite sul) percorreu-se o canal lagunar entre as ilhas, Mar de Cananéia, observando as margens até a Vila de Pedrinhas (limite Norte). Foram tomadas as coordenadas geográficas dos pontos de Spartina, o que depois seria tabulado e mapeado.

O Mar de Cananéia se apresenta bastante sinuoso, formando meandros e, por conseguinte, áreas pouco profundas, bancos de areia e ilhas sedimentares colonizadas por manguezais (Tessler \& Furtado, 1983). A presença da espécie foi constatada nas margens do canal, desembocaduras de rios e gamboas e na parte mais externa de algumas ilhas. 


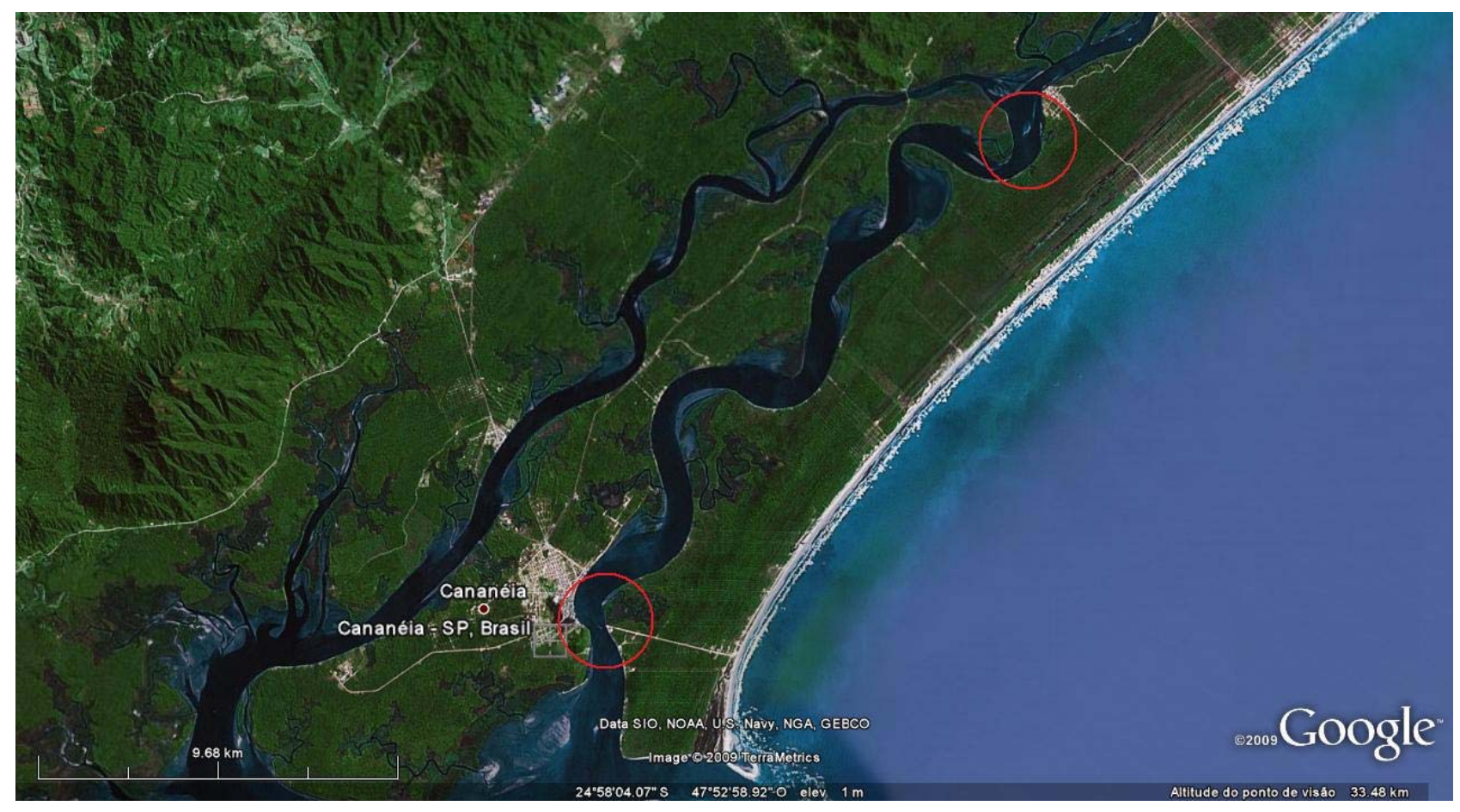

Figura 13. Os dois círculos vermelhos mostram os limites sul e norte das margens do Mar de Cananéia, onde foram feitas as coletas.

Área de coleta dos pontos de Spartina alterniflora

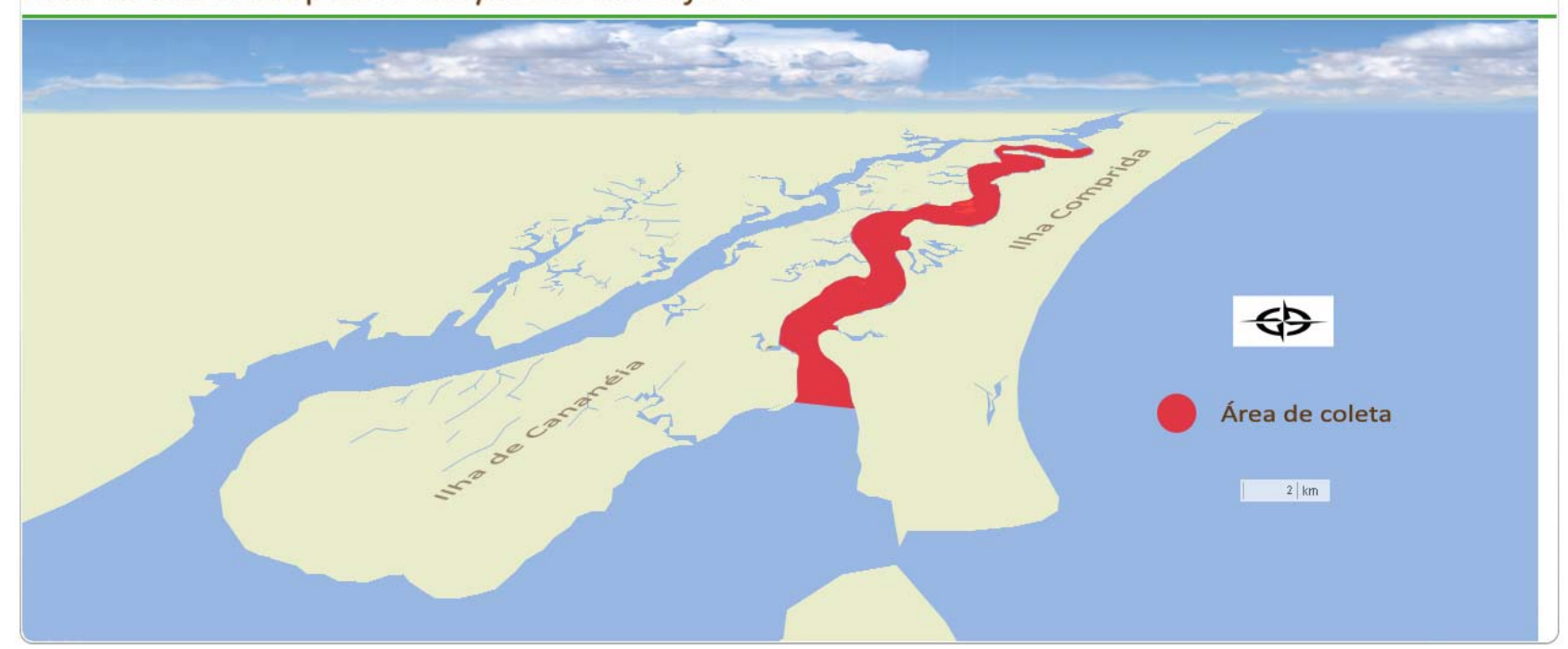

Figura 14: Infográfico da área de coleta dos pontos de Spartina alterniflora. 
Levando-se em conta as características da Spartina alterniflora, os trabalhos de campo foram programados de forma a abranger as variações sazonais anuais, representando bem nossos períodos seco e chuvoso.

Os pontos foram coletados à partir de um aparelho GPS Garmin eTrex de mão, utilizando coordenadas geográficas (latitudes e longitudes), que depois seriam convertidos para UTM.

$\mathrm{Na}$ caderneta de campo foram enumerados todos os pontos coletados, contando com a ajuda de símbolos que identificam a continuidade ou não das amostras. Para áreas com menos de 5 metros de comprimento desenhou-se um ponto ao lado do número que nomeava o ponto. Para áreas mais contíguas uma seta ligou os dois números dos dois pontos que limitavam a área. $\mathrm{A}$ seta tracejada indica falhas na continuidade.

Uma vez com as coordenadas dos pontos de Spartina em mãos, converteu-se as coordenadas de latitude/longitude para graus decimais ao serem tabulados. Os dados foram coletados e inseridos segundo o Sistema Geodésico Mundial - WGS84 (World Geodetic System) sobre uma imagem georreferenciada. Também inseriu-se utilizando o sistema Universal Transverso de Mercator - UTM SAD-69 (South America Datum), possibilitando saber, com mais praticidade, as distâncias em metros.

As atividades de campo foram realizadas na primavera de 2008, inverno e verão de 2009 . Em todos os campos foram amostrados uma média de 100 pontos, que representam os bancos de Spartina nas margens e ilhas do Mar de Cananéia.

Os bancos com a presença de S. alterniflora foram classificados de acordo com seu comprimento, 
margeando o canal. Em nenhuma oportunidade foi medida a largura dos bancos. A simples presença de Spartina alterniflora nas margens do canal, identificando sua presença, já seria representativo para a intenção do trabalho.

A espacialização dos bancos traz a informação dos possíveis locais de sedimentação e talvez colonização e expansão dos bosques de mangue.

\section{Resultados}

Os mapas confeccionados à partir dos pontos coletados registram a presença, o local e a extensão dos bancos de Spartina alterniflora. Os dados foram coletados na primavera e inverno, o que caracteriza o ápice de crescimento da gramínea e seu momento mais inerme.

A coleta nas duas margens do Mar de Cananéia procurou mostrar uma possível relação entre as ilhas de Cananéia e Comprida. Esta relação pode se deu através dos fluxos de energia, nutrientes e, o que cabe à esta pesquisa, transporte de sedimentos.

Através dos mapas é possível identificar os locais no Mar de Cananéia onde existe um maior potencial para a colonização de Spartina. Os meandros de baixa energia, onde há acúmulo de sedimentos, se mostraram locais propícios para a presença de bancos de S. alterniflora.

Esta caracterização da distribuição geográfica da Spartina foi de extrema importância, uma vez que forneceu as bases sobre o comportamento espacial da gramínea. 


\section{Ilha de Cananéia e Ilha Comprida:}

Spartina alterniflora

Primavera | 2008

Spartina alterniflora (até $5 \mathrm{~m}$ de extensão)

Spartina alterniflora

(mais de $5 \mathrm{~m}$ de extensão)

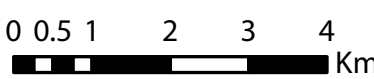




\section{Ilha de Cananéia e Ilha Comprida:}

Spartina alterniflora

Inverno| 2009

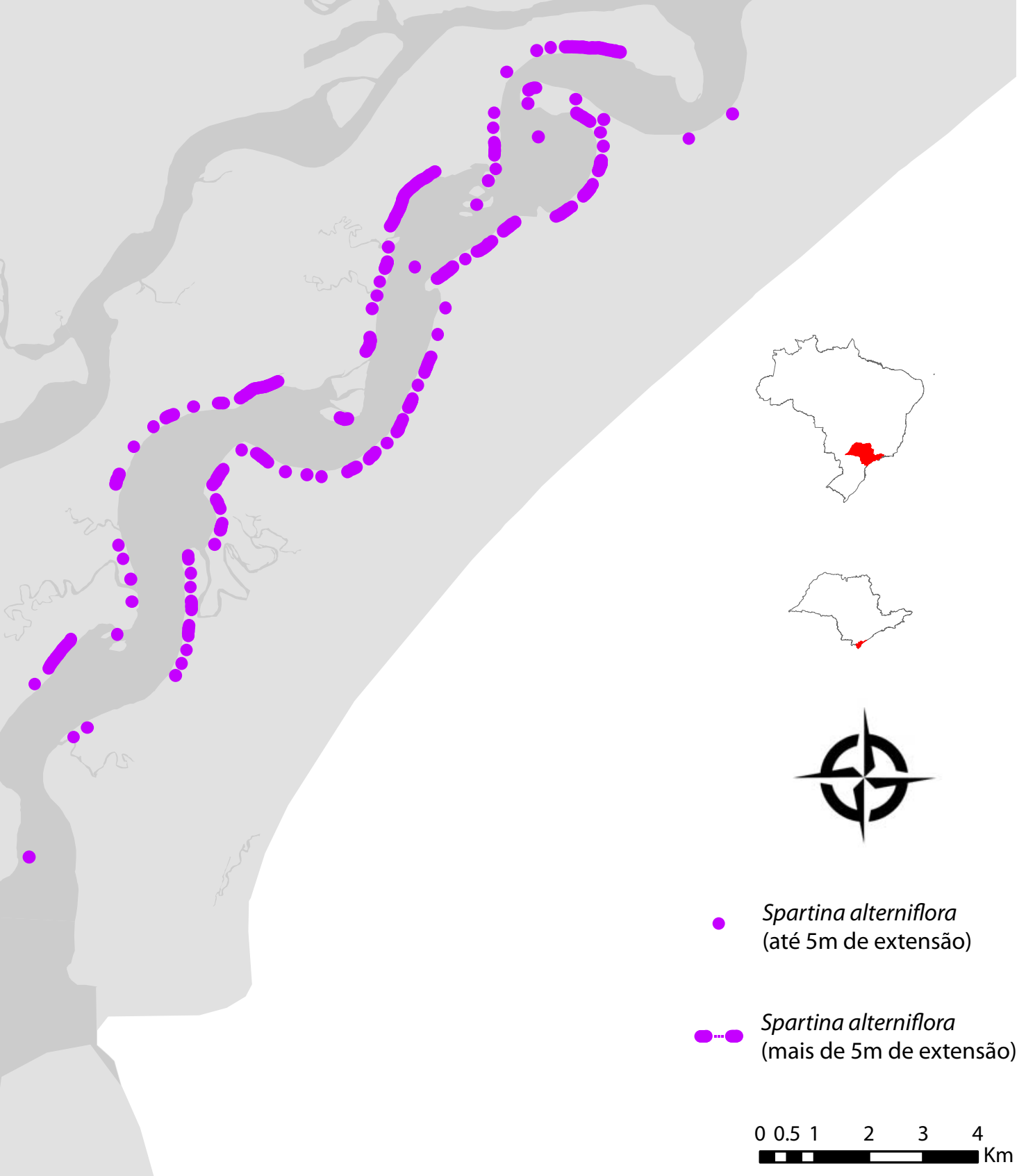




\section{Conclusão}

Spartina alterniflora e sedimentação

Em um ambiente semi-confinado como o sistema lagunar Cananéia-Iguape, que apresenta tendência ao assoreamento e conseqüente sedimentação, a interação entre substrato e vegetação é extremamente importante, uma vez que cria condições para futuras organizações espaciais. Em um primeiro momento, espécies pioneiras colonizam os depósitos de sedimentos expostos e, posteriormente, facilitam a colonização de outras espécies (Connel and Slatyer, 1977 apud Cunha-Lignon, 2009). Tal fato acontece nos canais lagunares de Cananéia, onde os bancos de areia são colonizados pela Spartina alterniflora, segurando e preparando o substrato para plântulas de espécies arbóreas dos manguezais da região.

Davis, já em 1940, identificou a presença de Spartina alterniflora em comunidades pioneiras e o papel fundamental na estabilidade dos sedimentos e na fixação de plântulas jovens de Rhizophora.

Um estudo de caso feito por Cunha-Lignon (2009) detalhou a variação espaço-temporal de bosques de mangue. Através de análise de imagens de satélite, fotografias aéreas e monitoramento de parcelas fixas, foram analisadas estrutura, zonação e sucessão dos bosques de mangues. A comparação de fotografias do litoral sul do estado de São Paulo, mostrou uma relação positiva entre aumento das áreas de deposição de sedimentos e aumento da área de manguezal. Os bancos de sedimento colonizados por bosques de mangue foram, primeiramente, ocupados por Spartina alterniflora (Figura 15). 
A maior densidade de plântulas e indivíduos jovens de mangue coloniza faixa de S. alterniflora, sendo pequena colonização no banco de sedimento. A colonização das plântulas acompanha a área de expansão da gramínea (Cunha-Lignon, 2005) (Figura 16).

É de fundamental importante a presença da Spartina alterniflora na fixação de sedimentos e estabelecimento de propágulos. Maiores densidades de plântulas e indivíduos jovens de mangue encontram-se em região colonizada pela gramínea, enquanto que nos bancos de sedimento exposto poucos propágulos se fixam (Cunha-Lignon, 2006) (Foto 1).

A Spartina alterniflora em bancos de sedimento em áreas de manguezais possibilita, prepara e facilita a colonização por plântulas de manguezais, promovendo a expansão do bosque de mangue. À medida que essa expansão vai acontecendo, os bosques de mangue vão substituindo as faixas antes ocupadas pela gramínea.

A presença de bancos de sedimentos ocupados por Spartina alterniflora nas franjas externas dos manguezais, na fácie de contato com os canais, evidencia o potencial de estabelecimento e expansão dos bosques de mangue. 


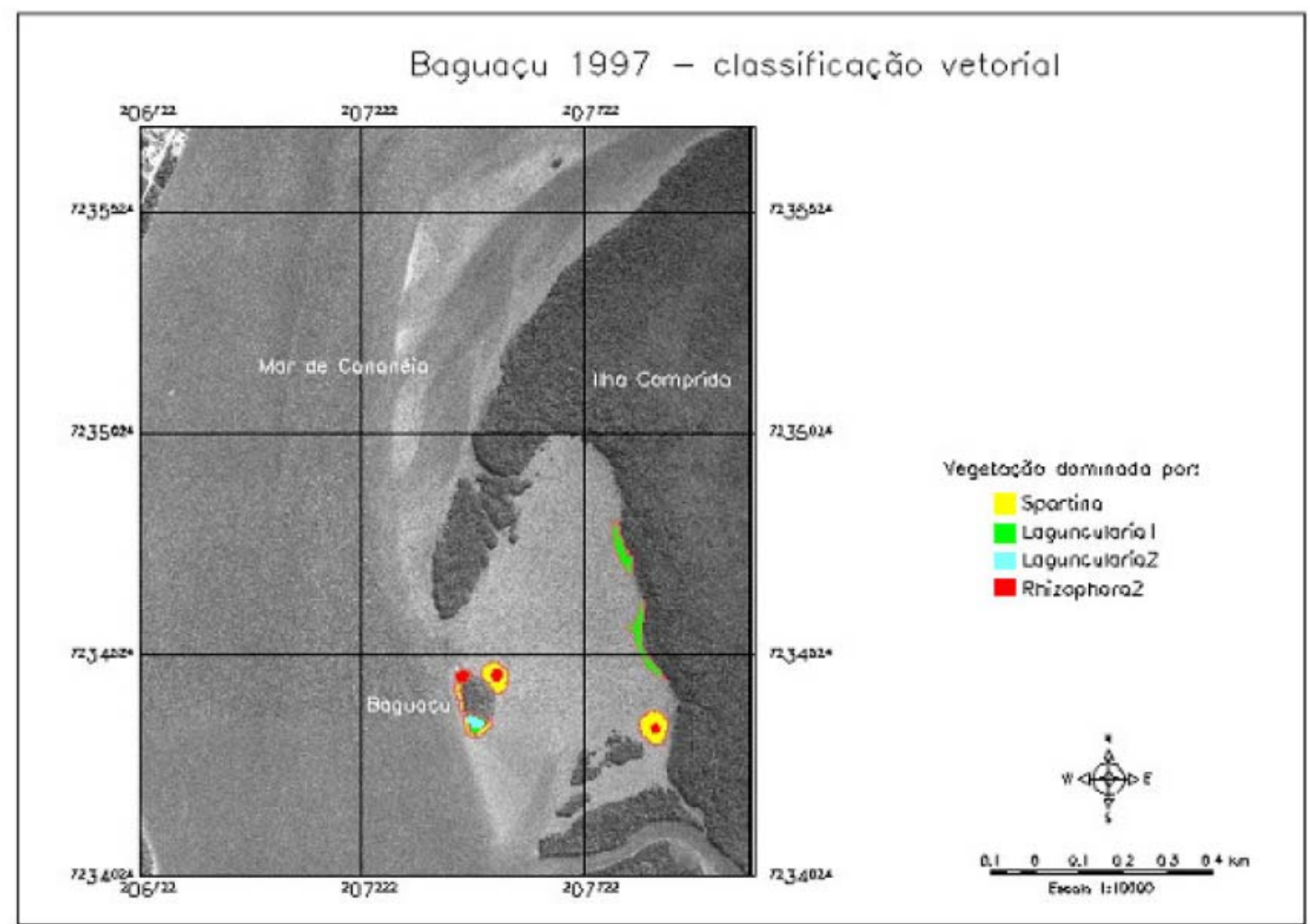

Figura 15. Bancos cobertos por Spartina alterniflora sendo colonizados por Rhizophora mangle (Cunha-Lignon, 2005).

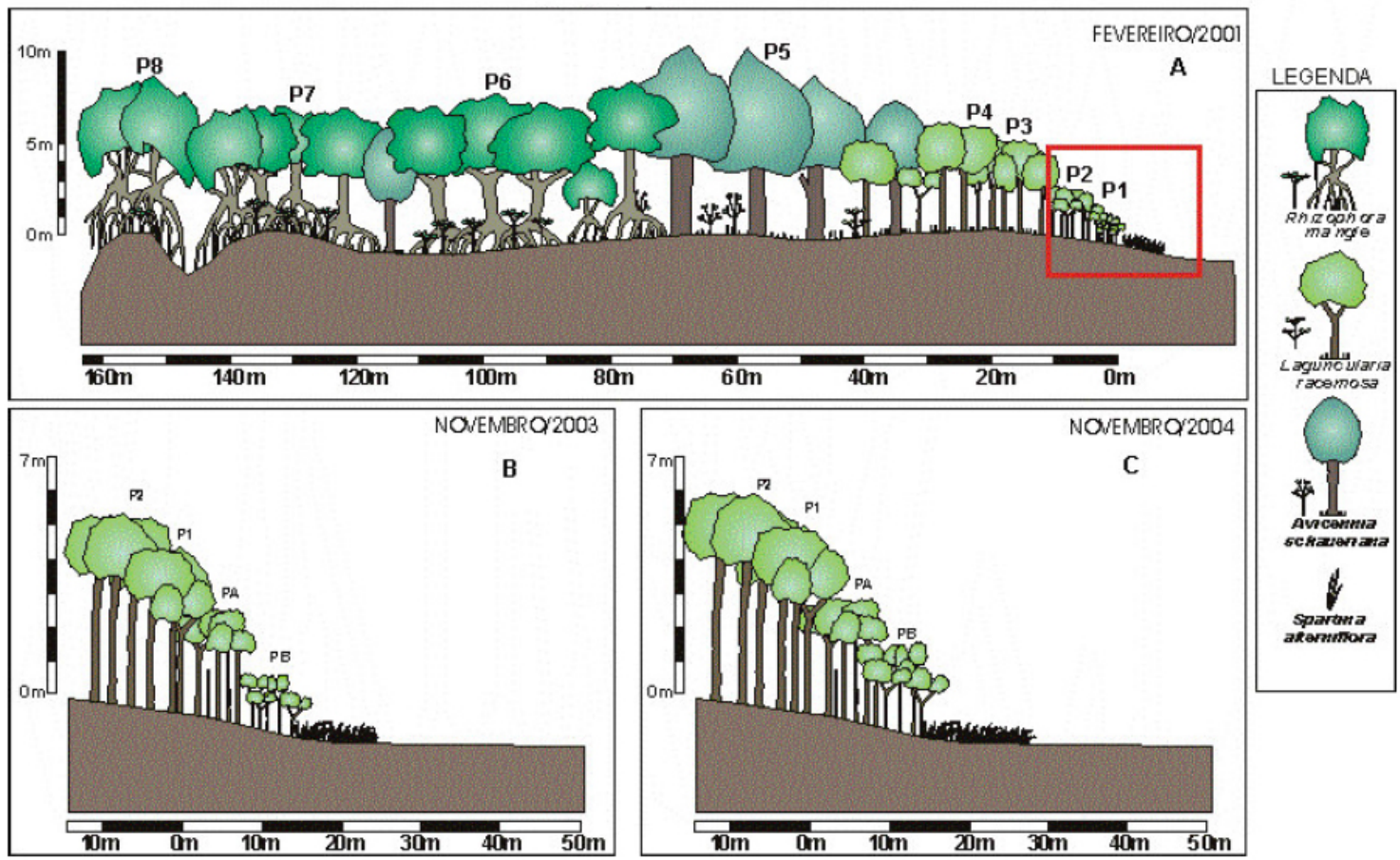

Figura 16. Desenvolvimento estrutural do bosque de mangue na Ilha de Baguaçu: a) parcelas estudadas por Cunha-Lignon, 2001; b) monitoramento em 2003; c) estrutura do bosque em 2004 (Cunha-Lignon, 2005). 

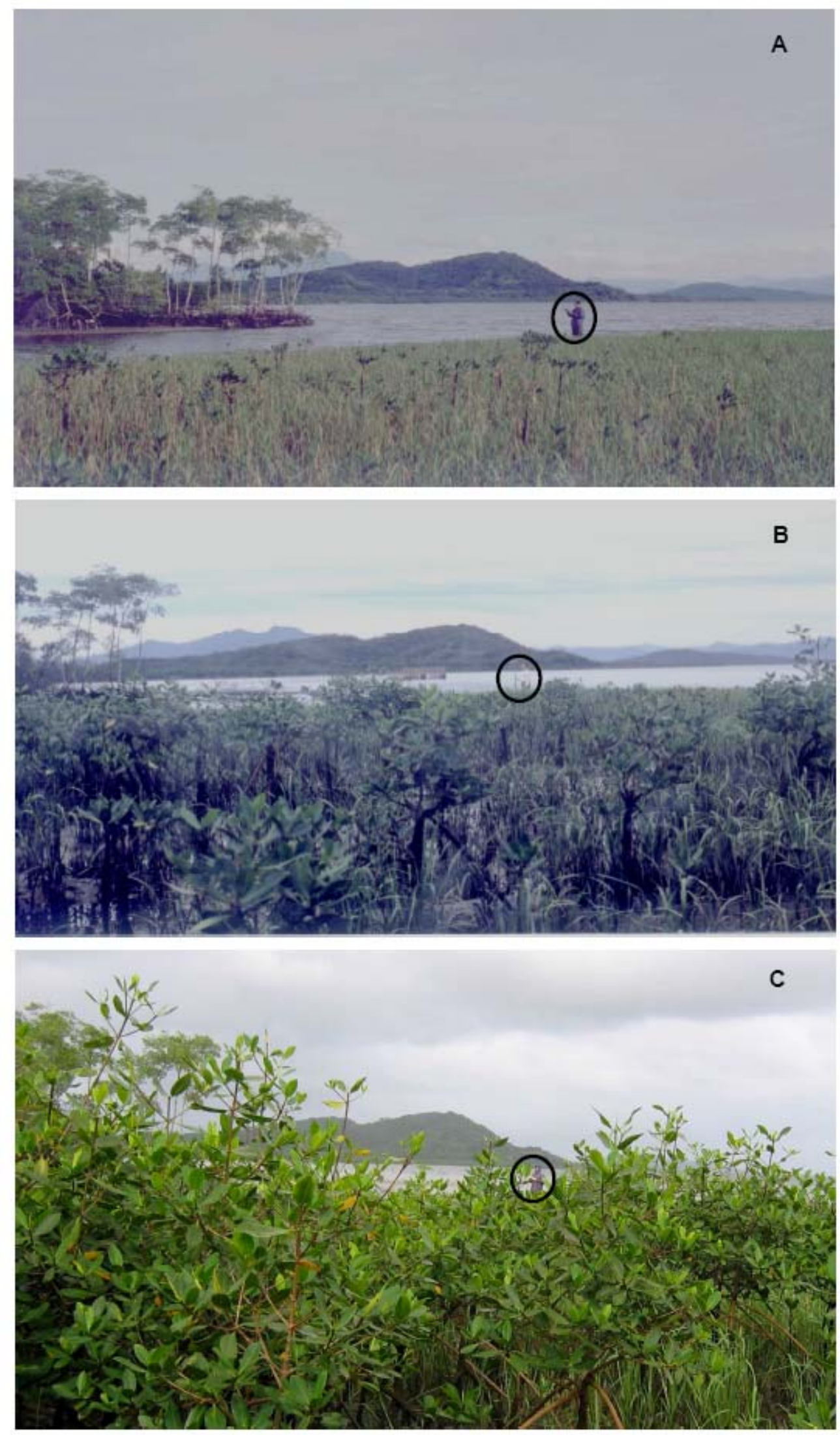

Foto 2. Banco de Spartina alterniflora sendo colonizado por Rhizophora mangle: a) Junho, 2001; b) Dezembro, 2003; c) Novembro, 2004 (Cunha-Lignon, 2005). 


\section{Considerações Finais}

Ficam claros o papel e importância que a gramínea Spartina alterniflora possui perante ao ecossistema de manguezais em que ela se encontra, no sistema Lagunar de Cananéia-Iguape.

Identificar os locais com tendências ao crescimento de Spartina, entender as características que geram esta tendência, entender o comportamento da gramínea durante e depois de sua fixação e as possibilidades que ela gera para a colonização de espécies de mangue; estes dados nos fornecem conhecimento do fluxo (correntes) e matéria (sedimentos).

A caracterização da distribuição geográfica da espécie, possibilitou uma análise da relação: baixa energia, sedimentação e pioneirismo da Spartina. Um estudo de longo prazo poderia mostrar etapas de colonização de bosques de mangue após a instalação e permanência desta relação. $O$ provável desenvolvimento do manguezal nestes bancos de Spartina, como outros estudos já mostraram, contribuiria ainda mais no seu papel de proteção e fornecimento de nutrientes aos ambientes costeiros.

Quanto à conectividade, o grande objetivo alcançado por este trabalho foi promover e instigar o conhecimento de suas várias esferas de atuação. As diferentes escalas em que a conectividade atua mostram que sua importância vai além do tangível, nos despertando para o entendimento do sistema como um todo.

A obtenção de dados que mostrem a origem e o provável destino de sedimentos e nutrientes requereria análises laboratoriais que fogem do alcance deste trabalho. É certo que tais dados enriqueceria bastante a discussão. 
Todo o agrupamento e análise de informações realizados, principalmente, em torno da tríade Spartina alterniflora, conectividade e sedimentação, fez com que esta pesquisa atingisse seu objetivo maior. 


\section{Bibliografia}

Ab'Saber, A. N. (2003) Os domínios de natureza no Brasil: potencialidades paisagísticas. São Paulo: Ateliê Editorial.

Adaime, R. R. (1977) Estudo da variação estacional do "standing crop" e do repovoamento de um banco de S. alterniflora Loiseleur, 1807, no complexo estuarino-lagunar de Cananéia. Tese de Mestrado, Universidade de São Paulo, São Paulo, Brasil.

Adams, D. A. (1963) Factors influencing vascular plant zonation in North Carolina salt marshes. Ecology, Vol.44, No.3, pp. 445-456.

Alves, L. F. (2004) Efeito da conectividade na abundância e riqueza de plântulas e jovens de espécies arbóreas em paisagens fragmentadas. Relatório Técnico - Bolsa de PósDoutoramento/FAPESP (Processo No 00/03945-6) vinculada ao Programa BIOTA/FAPESP: Conservação da Biodiversidade em Paisagens Fragmentadas no Planalto Atlântico de São Paulo (Processo No 99/05123-4). . Sub-Projeto 7.

Alves, L. F. e J. P. Metzger, J. P. (2002) Fragmentation effects on tree seedling density in a tropical agricultural landscape of southeastern Brazil. In: 45th Symposium of the International Association for Vegetation Science, Porto Alegre, Brazil, p. 102

Bennet, A.F. (2003) Linkages in the landscape: the role of corridors and connectivity in wildlife conservation. IUCN, Gland, Switzerland and Cambridge, UK. 
Bérgamo, A.L. (2000) Características da hidrografia, circulação e transporte de sal: Barra de Cananéia, Sul do Mar de Cananéia e Baía de Trapandé. Dissertação de Mestrado, Universidade de São Paulo, Instituto Oceanográfico, USP, 210p.

Bertrand, G. (1971) Paisagem e Geografia Física Global: esboço metodológico. Universidade de São Paulo: Instituto de Geografia.

Besnard, W. (1950) Considerações gerais em torno da região lagunar Cananéia-Iguape. Bolm. Inst. Paul. Oceanogr., 1(1): 3-28.

Besnard, W. (1950a) Considerações gerais sobre em torno da região lagunar de Cananéia-Iguape I. Bol. Inst. Paul. Oceanogr., São Paulo, 1 (1): 9-26.

Besnard, W. (1950b) Considerações gerais sobre em torno da região lagunar de Cananéia-Iguape II. Bol. Inst. Paul. Oceanogr., São Paulo, 1 (2): 3-28.

Bianchini Jr., I. (1982) Contribuição ao estudo da decomposição de plantas aquáticas. Tese de Mestrado, Universidade Federal de São Carlos, São Carlos, Brasil.

Bianchini Jr., I. (1984) Estudos dos processos de humificação de Nymphoides indica (L.) O. Kuntze. Tese de Doutorado, Universidade Federal de São Carlos, São Carlos, Brasil.

Bittencourt, A. C. S. P.; Vilas-Boas, G. S. \& Flexor, J. M. (1979) Quaternary marine formations of the coast of the State of Bahia, Brazil. In: International Symposium on coastal evolution in the quaternary, São Paulo, 1978. Proceedings. São Paulo, 1978, p. 232-253. 
BRASIL. (2003) Estatística da Pesca 2001 - Grandes Regiões e Unidades do Brasil. Tamandaré - PE: Ministério do Meio Ambiente, Instituto Brasileiro do Meio Ambiente e dos Recursos Naturais Renováveis.

BRASIL. (2004) Estatística da Pesca 2002 - Grandes Regiões e Unidades do Brasil. Tamandaré - PE: Ministério do Meio Ambiente, Instituto Brasileiro do Meio Ambiente e dos Recursos Naturais Renováveis.

BRASIL. (s/d) Estatística da Pesca 2000 - Grandes Regiões e Unidades do Brasil. Ministério do Meio Ambiente, Instituto Brasileiro do Meio Ambiente e dos Recursos Naturais Renováveis.

Brown, J.H. \& Kodric-Brown, A. (1977) Rates in insular biogeography: effect of immigration on extinction. Ecology, Vol.58, No.2, pp. 445-449.

Bunn, A.G., Urban, D.L. \& Keitt, T.H. (2000) Landscape connectivity: a conservation application of graph theory. Journal of Environmental Management, Vol.59, pp. 265-278.

Cammen, L. M.; Rublee, P.; Hobbie, J. (1978) Bacteria in a North Carolina salt marsh: standing crop and importance in the decomposition of Spartina alterniflora. Univ. of North Carolina Sea Grant Publ. UNC-SG 74-75.

Cammen, L.M. (1980) The significance of microbial carbon in the nutrition of deposit feeding polychaete Nereis succinea. Marine Biology, Vol.61, pp. 9-20.

Chapman, V. J. (1974) Salt marshes and deserts of the world. 2nd Ed. J. Cramer Verlag, Leutershausen, Germany. 
Christiansen, T.; Wiberg, P. L.; Milligan, T. G. (2000) Flow and sediment transport on a tidal salt marsh surface. Estuarine, Coastal and Shelf Science, Vol.50, pp. 315-331.

Cody, M.L. \& Diamond, J.M. (ed) (1982) Ecology and evolution of communities. The Belknap Press of Harvard University Press, England.

Costa, C. S. B.; Davy, A. J. (1992) Coastal saltmarsh communities of Latin America. In Seeliger, U. (ed) Coastal plant communities of Latin America. Departamento de Oceanografia, Universidade do Rio Grande, Rio Grande, Brazil.

Cowen, R.K. et al. (2000) Connectivity of marine populations: open or closed? Science Vol.287, pp. 857-859.

Craft, C.; Megonigal, P.; Broome, S.; Stevenson, J.; Freese, R.; Cornell, J.; Zheng, L.; Sacco, J. The pace of ecosystem development of constructed Spartina alterniflora marshes. Ecological Applications, Vol.13, No.5, pp. 1417-1432.

Cunha-Lignon, M. (2001) Dinâmica do manguezal no Sistema de Cananéia-Iguape, Estado de São Paulo - Brasil. Dissertação de Mestrado, Instituto Oceanográfico, Universidade de São Paulo.

Cunha-Lignon, M. (2001) Dinâmica do manguezal no Sistema de Cananéia-Iguape, Estado de São Paulo - Brasil. Dissertação de Mestrado, Universidade de São Paulo, Instituto Oceanográfico de São Paulo. 
Darnell, R. M. (1967a) The organic detritus problem. In Lauff, G. H. (ed) Estuaries. American Association for the advancement of science, No.83.

Darnell, R. M. (1967b) Organic detritus in relation to the estuarine ecosystem. In Lauff, G. H. (ed) Estuaries. American Association for the advancement of science, No.83.

Davis, J. H. (1940) The ecology and geologic role of mangroves in Florida. Carnegie Institute Washington Publication, n. 517, p. 303-412.

Diamond, J.M. (1975) The island dilemma: lessons of modern biogeographic studies for the design of natural reserves. Biological Conservation Vol. 7, no. 2, pp. 129-146.

Diegues, A. C. S. (2000). Etnoconservação: novos rumos para a conservação da natureza. São Paulo: Nupaub/USP.

Diegues, A. C. S. (2001). Ecologia humana e planejamento em áreas costeiras. São Paulo: Nupaub/ USP.

Dunning, J.B.; Danielson, B.J. \& Pulliam, H.R. (1992) Ecolgical precesses that affect populations in complex landscapes. Oikos, Vol.65, No.1, pp. 169-175. Nordic Society Oikos.

Forman, R. T. T. \& Godron, M. (1986) Landscape ecology. New York: John Wiley \& Sons Inc.

Forman, R.T.T. (1995) Land mosaics: the ecology of landscapes and regions. Cambridge University Press, UK. 
Freitas, R. O. de (1947) Eruptivas alcalinas de Cananéia, Estado de São Paulo. Bol Fac. Fil. Ciên. Letras da Univ. de São Paulo, no. 91, Geol. no. 4, São Paulo.

Fritz, R. \& Merriam, G. (1992) Fencerow habitats for plants moving between farmland forests. Biological Conservation 64, pp. 141-148. Elsevier Science Publishers Ltd, England.

Goodman, P. J. (1958) Spartina Schreb. The Journal of Ecology, Vol.57, No.1, pp. 285-287.

Gosselink, J. G.; Kirby, C. J. (1974) Decomposition of Salt Marsh Grass, Spartina alterniflora Loisel. Limnology and Oceanography, Vol.19, No.5, pp. 825-832.

Guerra, A. J. T.; CUNHA, S.B. da (Org). (1998) Geomorfologia do Brasil. Rio de Janeiro: Bertrand Brasil.

Haines, E. B. (1977) The origins of detritus in Georgia salt marsh estuaries. Oikos, 29, pp. 254-260. Helliwell, D.R. (1975) The distribution of woodland plant species in some shroshire hedgerows. Biol. Conserv. 7, pp. 61-72. Applied Science Publishers Ltd, England.

Henein, K. \& Merriam, G. (1990) The elements of connectivity where corridor quality is variable. Landscape Ecology, Vol.4, Nos. 2/3, pp. 157-170.

Hobbs, R.J. \& Saunders, D.A. (ed) (1992) Reintegrating fragmented landscapes: towards sustainable production and nature conservation. New York: Springer-Verlag. 
Holt, R.D., Robinson, G.R. \& Gaines, M.S. (1995) Vegetation dynamics in an experimentally fragmented landscape. Ecology, Vol.76, No.5, pp. 1610-1624.

Kareiva, P. \& Wennergren, U. (1995) Connecting landscape patterns to ecosystem and population porcesses. Nature, Volume 373, Issue 6512, pp. 299-302.

Karniol-Marquez, M. da R. (2007) Morfodinâmica de um segmento da praia da llha Comprida, litoral sul do Estado de São Paulo. Dissertação de mestrado. Instituto Ocenográfico, Universidade de São Paulo.

Kutner, A. S. (1962) Granulometria dos sedimentos de fundo da região de Cananéia, São Paulo. Bol. Soc. Bras. Geol. vol. 11, no. 2, p. 41-45, São Paulo.

Leonard, L. A.; Wren, P. A.; Beavers, R. L. (2002) Flow dynamics and sedimentation in Spartin alterniflora and Phragmites australis marshes of the Chesapeake Bay. Wetlands, Vol.22, No.2, pp. 415-424.

MacArthur, R.H. \& Wilson, E.O. (1967) The theory of island biogeography. Princeton, N.J.: Princeton University Press.

Mann, K. H. (1975) Relationship between morphometry and biological functioning in three coastal inlets of Nova Scotia. Estuarine Research, Vol.1, pp. 634-644

May, M. S. (1974) Probable agents for the formation of detritus from the halophyte, Spartina alterniflora. In Reimold, R. J. (ed) Ecology of Halophytes. University of Georgia Marine Insitute, 
Sapelo Island, Georgia, USA.

McKee, K. L. (1988) The relation of smooth cordgrass (Spartina alterniflora) to tidal datums: a review. Estuaries, Vol.11, No.3, pp. 143-151.

Mendelssohn, I. A. (1979) The influence of nitrogen level, form, and application method on the growth response of Spartina alterniflora in North Carolina. Estuaries, Vol.2, No.2, pp. 106-112. Mendonça, F. (2001) Geografia socioambiental. São Paulo: Terra Livre, 16: 139-158.

Mesquita, A.L. de \& Harari, J. (1983) Tides and gauges of Cananéia and Ubatuba - Brasil (Lat $24^{\circ}$ ). Relat. Int. Inst. Oceanogr. Univ. S. Paulo, (11): 1-14.

Metzger, J. P. (2001) O que é ecologia de paisagens? São Paulo: Departamento de Ecologia, Instituto de Biociências/USP. Disponível em: <http://www.biotaneotropica.org.br>. Acesso em: 23 mai. 2007.

Metzger, J. P. (2003) Conservação da Biodiversidade em Paisagens Fragmentadas no Planalto Atlântico de São Paulo. III Relatório Anual FAPESP (Programa BIOTA/FAPESP, Processo $\mathrm{n}^{\circ}$ 99/05123-4)

Metzger, J.P. \& Décamps, H. (1997) The structural connectivity threshold: an hypothesis in conservation biology at the landscape scale. Acta Oecologica Vol.18 (1), pp. 1-12.

Miniussi, I. C. (1959) Propagação da onda de maré em torno da llha de Cananéia. Contrções Inst. oceanogr. Univ. São Paulo, série Oceanogr. fís., (2): 1-8. 
Miranda, E. E. de; Coutinho, A. C. (Coord.). (2004) Brasil Visto do Espaço. Campinas: Embrapa Monitoramento por Satélite. Disponível em: <http://www.cdbrasil.cnpm.embrapa.br>. Acesso em: 02 jul. 2005.

Mobberley, D. G. (1956) Taxonomy and distribution of the genus Spartina. lowa State College Journal of Science, Vol.30, No.4, pp. 471-574.

Moraes, A. C. R. (1999) Contribuições para a gestão da zona costeira do Brasil: elementos para uma geografia do litoral brasileiro. São Paulo: Hucitec; Edusp.

Nixon, S. W.; Oviatt, C. A. (1973a) Analysis of local variation in the standing crop of Spartina alterniflora. Botanica Marina, Vol.16, pp. 103-109.

Nixon, S. W.; Oviatt, C. A. (1973b) Ecology of a New England Salt Marsh. Ecological Monographs, Vol.43, No.4, pp. 463-498.

Noss, R.F. (1991) Landscape connectivity: different functions at different scales. pp.27-39 in Landscape linkages and biodiversity. (Ed. W. E. Hudson). (Island Press: Washington DC).

Noss, R.F. \& Larry, D.H. (1986) Nodes, networks and MUMs: preserving diversity at all scales. Environmental Management. Vol.10, No.3, pp. 299-309. Springer-Verlag New York Inc.

Odum, E. P. (1965) Ecologia: estructura y funcion de la natureza. Los modernos principios de flujos de energia y ciclos biogeoquimicos. México: Continental. 
Odum, E. P.; de la Cruz, A. (1967) Particulate detritus in a Georgia salt marsh-estuarine ecosystem. In Lauff, G. H. (ed) Estuaries. American Association for the advancement of science, No.83.

Panitz, C. M. N. (1992) Ecological aspects of a saltmarsh ecosystem in Santa Catarina Island, Brazil. In Seeliger, U. (ed) Coastal plant communities of Latin America. Departamento de Oceanografia, Universidade do Rio Grande, Rio Grande, Brazil.

Pereira, O. M. et al. (2001) Avaliação do estoque da ostra Crassostrea brasiliana em rios e gamboas da região estuarino-lagunar de Cananéia. São Paulo: B. Inst. Pesca, 27(1): 85-95.

Pereira, O. M. et al. (2000) Avaliação dos estoque da ostra Crassostrea brasiliana (Lamarck, 1819) no manguezal da região estuarino-lagunar de Cananéia. São Paulo: B. Inst. Pesca, 26(1): 49-62.

Pereira, O. M. et al. (1985) Hidrografia do complexo estuarino-lagunar de Cananéia: salinidade e temperatura (1973 a 1980). São Paulo: B. Inst. Pesca, 12(3): 109-21.

Pereira, O. M. et al. (1986) Hidrografia do complexo estuarino-lagunar de Cananéia: influência da maré. São Paulo: B. Inst. de Pesca, 13(1): 51-70.

Preston, F.W. (1962) The canonical distribution of commonness and rarity: part II. Ecology, Vol.43, No.3, pp.410-432. Ecological Society of America.

Redfield, A. C. (1965) Ontogeny of a salt marsh estuary. Science, Vol.147, No.3653, pp. 50-54. 
Reed, D. J. (1989) Patterns of sediment deposition in subsiding coastal salt marshes, Terrebonne Bay, Louisiana: the role of winter storms. Estuaries, Vol.12, No.4, pp. 222-227.

Reitz, P. R. (1961) A vegetação da zona marítima de Santa Catarina. Sellowia, Vol.13, No.13, pp. 17115.

Ross, J.F.S. (1997) Mapa geomorfológico do Estado de São Paulo. Laboratório de Geomorfologia, Departamento de Geografia. Faculdade de Filosofia Letras e Ciências Humanas, Universidade de São Paulo.

Sakamoto, L. Fazendas de Água. Disponível em: <www.reporterbrasil.com.br/reportagens/pesca/ pesca.pdf>. Acesso em: 30 jun. 2005.

Scott, P. C. (1986) Considerações sobre o uso da Baía de Sepetiba, RJ para a Maricultura apoiadas num Sistema de Informação Geográfica. Instituto de Ciências Biológicas e Ambientais, Universidade Santa Úrsula, RJ.

Silva, J.F. (1989) Dados climatológicos de Cananéia e Ubatuba (Estado de São Paulo). Bolm. Climatol. Inst. Oceanogr., São Paulo, (6): 1-21.

Silveira, J. D. (1970) Morfologia do Litoral. In: AROLDO, A. Brasil, a terra e o homem. São Paulo: Nacional.

Soctchava, V. B. (1978) Por uma teoria de classificação de geossistemas de vida terrestre. Universidade de São Paulo: Instituto de Geografia. 
Spinelli, F.P. (2003) As rochas alcalinas de Cananéia, litoral sul do Estado de São Paulo: características petrográficas, mineralógicas e geoquímias. Dissertação de Mestrado, Universidade de São Paulo, Instituto de Geociências, 134p.

Squiers, E. R.; Good, R. E. (1974) Seasonal changes in the productivity, caloric content, and chemical composition of a population of salt-marsh cord-grass (Spartina alterniflora). Chesapeake Science, Vol.15, No.2, pp. 63-71.

Suguio, K \& Martin, L. (1978) Formações quaternárias marinhas do litoral paulista e sul fluminense. In: International Symposium on Coastal Evolution in the Quaternary. Special publication. Sociedade Brasileira de Geologia. Instituto de Geociências, Universidade de São Paulo. 55p.

Suguio, K. \& Martin, L. (1978) Quaternary marine formations of the States of São Paulo and southern Rio de Janeiro. In: International Symposium on coastal evolution in the quaternary, São Paulo, 1978. Special Publication, no. 1, 55p.

Suguio, K. \& Martin, L. (1986) Quaternary marine formations of the State of São Paulo and Southern Rio de Janeiro. Intern. Symposium on Coastal Evolution in the Quaternary, Special Publication, São Paulo, Soc. Bras. Geologia, Vol. 1, 55p.

Suguio, K. \& Petri, S. (1973) Stratigraphy of the Iguape-Cananéia lagoonal region sedimentary deposits, São Paulo, Brazil. Part I: Field observations and grain size analysis. Bolm IG, Inst. Geociên., Universidade de São Paulo, 4: 1-20. 
Suguio, K. \& Tessler, L. A. P. (1992) Depósitos quaternários da planície costeira de CananéiaIguape (SP). Roteiro das Excursões do 37o Congresso Brasileiro de Geologia, Vol I, 31 p.

Suguio, K. \& Tessler, M. G. (1992) Depósitos quaternários da planície costeira de Cananéia-Iguape (SP). Publicação Especial do Instituto Oceanográfico de São Paulo, n.9, p. 1-33.

Taylor, P.D.; Fahrig, L.; Henein, K. \& Merriam, G. (1993) Connectivity is a vital element of landscape structure. Oikos, Vol.68, No.3, pp. 571-573. Nordic Society Oikos.

Teal, J. M. (1962) Energy Flow in the Salt Marsh Ecosystem of Georgia. Ecology, Vol.43, No.4, pp. 614-62

Tessler, M. G. \& Furtado, V. V. (1983) Dinâmica de sedimentação das feições de assoreamento da região lagunar Cananéia-Iguape, Estado de São Paulo. Bolm. Inst. Oceanogr., São Paulo, 32 (2): 117-124.

Tessler, M. G. (1982). Sedimentação atual na região lagunar de Cananéia-Iguape, Estado de São Paulo. Dissertação de Mestrado, Universidade de São Paulo, Instituto de Geociências, v. 1 (texto) 110p. e v. 2 (mapas e figuras) 170p.

Tessler, M. G. (1994) Geologia da plataforma continental e costeira. Meteorologia. Diagnostico ambiental oceânico e costeiro das regiões sul e sudeste do Brasil. São Paulo: Fundespa - lousp Petrobras. 
Tessler, M. G. \& Souza, L. A. P. (1998) Dinâmica sedimentar e feições sedimentares identificadas na superfície de fundo do sistema Cananéia-Iguape, SP. Rev. Bras. de Oceanogr., 46 (1): 69-83.

Tessler, M. G. \& Souza, L. A.P. de (1998) Dinâmica sedimentar e feições sedimentares identificadas na superfície de fundo do sistema Cananéia-lguape, SP. Rev. bras. oceanogr., 46 (1)

Tischendorf, L. \& Fahrig, L. (2000) How should we measure landscape connectivity? Landscape Ecology, Vol. 15, pp. 633-641.

Tomlinson, P. B. (1986) The botany of mangroves. Cambridge University Press, Cambridge, England.

Turner, R. E. (1976) Geographic variations in sat marsh macrophyte production: a review. Contributions in Marine Science, Vol.20, pp. 47-68.

Urban, D. \& Keitt, T. (2001) Landscape connectivity: a graph-theoretic perspective. Ecology, Vol.82, No.5, pp. 1205-1218.

Valenti, W. C. (2000) Aqüicultura no Brasil: bases para um desenvolvimento sustentável. Ministério da Ciência e Tecnologia.

Valiela, I. (1974) Nutrient limitation in a salt marsh vegetation. In Reimold, R. J. (ed) Ecology of Halophytes. University of Georgia Marine Insitute, Sapelo Island, Georgia, USA. 
Vanucci, M. (2002) Os manguezais e nós: uma síntese de percepções. São Paulo: Edusp.

Vrieling, A. \& Sanden, J. van der. (2000) Satellite remote sensing for monitoring coastline dynamics of the Canadian beaufort sea coast. Canada Centre for Remote Sensing.

Whittaker, R. J. (1998) Island biogeography: ecology, evolution, and conservation. New York: Oxford University Press.

Wiegert, R. G. (1977) Ecological processes characteristic of coastal Spartina marshes of the southeastern U.S.A. In Jefferies, R. L. (ed) Ecological processes in coastal environments. Blackwell Scientific Publications.

Wilson, E.O. \& Willis, E.O. (1975) Applied Biogeography. In: Cody, M. L. \& Diamond, J. M. (ed) Ecology and evolution of communities. Belknap Press of Harvard University Press: Cambridge, Massachusetts and London: England.

Zalewski, M. (2004) Do smaller islands host younger populations? A case study on metapopulations of three carabid species. Journal of Biogeography, Vol.31, pp. 1139-1148.

Zollner P.A. \& Lima, S.L. (1999) Strategies for landscape-level interpatch movements. Ecology, Vol.80, No.3, pp. 1019-1030.

Zunino, M. \& Zullini, A. (2003) Biogeografia: la dimensión espacial de la evolución. México: Fondo de Cultura Económica. 